\title{
Growing World Trade: Causes and Consequences
}

What aspect of the American economy has changed most in the twenty-five years since Brookings Papers on Economic Activity first began appearing? If you took a poll of economic journalists, businessmen, or policy intellectuals other than professional economists, globalization-the growing integration of the United States with the world economy-would probably top the list. It is now conventional wisdom in many circles that the growth of world trade and investment has transformed the ground rules for economic policy.

Admittedly, many international economists regard the popular conviction that unprecedented globalization has changed everything as considerably exaggerated; Americans are still so taken with the novelty of extensive international trade that they have yet to acquire a sense of perspective about its importance. Even today the shares of imports and exports in America's GDP are only about half of what they were in the United Kingdom thirty years ago; the U.S. economy is not now, and may never be, as dependent on exports as Britain was during the reign of Queen Victoria. Nonetheless, international trade has certainly increased considerably since the 1960 s. In 1960 the share of trade-measured as the average of imports and exports of goods and services-in America's GDP was 4.7 percent; in 1994 it was 11.4 percent, an increase of more than 100 percent. While the growth of trade has not been quite as dramatic in other advanced countries, it has also been considerable: the average OECD country had a trade share of 12.5 percent in 1960 , 18.6 percent in 1990. And a number of developing countries have seen

I would like to thank T.N. Srinivasan, Richard Cooper, and William Nordhaus for helpful comments. 
their trade explode: China, virtually isolated from the world economy before 1978, may now export 25 percent of its GDP.

Why has world trade grown, and what are the consequences of that growth? These are surprisingly disputed issues. This is true to a limited extent because of disagreements among professional economists, notably about the relative importance of trade and technological change in causing the growing inequality of wages in advanced nations. Even more striking is the gap between professional opinion and the broader conventional wisdom. There are a number of cases in which the perceptions of noneconomists who believe themselves to be well-informed about the world economy are radically at odds with what research seems to indicate. To take a relatively mild example: most journalistic discussion of the growth of world trade seems to view growing integration as driven by a technological imperative-to believe that improvements in transportation and communication technology constitute an irresistible force dissolving national boundaries. International economists, however, tend to view much, though not all, of the growth of trade as having essentially political causes, seeing its great expansion after World War II largely as a result of the removal of the protectionist measures that had constricted world markets since 1913. At least implicitly, therefore, they also tend to see the trend toward growing integration as potentially reversible.

And yet perhaps these disagreements should not be all that surprising. International trade is, after all, the prime example of a subject in which it is essential to take account of general equilibrium, in which everything affects everything else in at least two ways. The generalequilibrium aspects of international economic issues can cause confusion even among the experts. For example, how should one think about the effects of technology on income distribution? Should one, as Edward Leamer appears to believe, model the effects of technological change by thinking of that change as occurring in isolation in a single country that faces given world prices? ${ }^{1}$ Or should one, like most of those who believe that technological change is the main cause of rising inequality, think of it as happening simultaneously in a number of countries that collectively constitute a more or less closed economy? These two approaches can give radically different predictions.

\section{Leamer (1994).}


And if even the professors can get confused, the broader public-including commentators who can sound convincing but do not have the patience to work through all the implications of their ideas-is all the more subject to befuddlement. An astonishing amount of the public discussion of international economic issues, among people who believe themselves to be sophisticates, involves sheer misunderstanding of accounting identities; and it goes without saying that almost nobody understands such abstruse concepts as comparative advantage.

In any case, this paper represents an attempt to shed some light on the causes and implications of growing world trade. The issues discussed here are the subject of a huge recent literature; the distinctive feature of the analysis in this paper is an attempt to keep in mind throughout that world trade must be regarded as the outcome of a process in which trade flows, world prices, wages, and employment are all simultaneously determined.

The paper is in five parts. The first part presents an overview of trends in world trade; it looks at the long-run evolution of world trade, and tries to identify those aspects of globalization that are truly new. The second part asks the question, why has world trade increased? The last three parts are devoted to the issue that has created the most controversy in recent discussions of international trade: the effects of exports of manufactures from the third world on wages and employment in the first. I begin by setting out a stylized, minimalist general-equilibrium model of world trade, wages, and employment, and suggest a set of ballpark parameters for that model. I then turn to a theoretical and numerical assessment of the impact of the new phenomenon of low-wage exports under two different sets of assumptions. First is a "European" approach, in which the advanced world as a whole is assumed to have inflexible relative wages, and in which the effects of trade are manifested in changes in employment. As far as I know, this approach is new-the rapidly growing literature on trade and wages has consistently assumed that wages are flexible and that full employment is maintained. It turns out, however, that the rigid-wage case is not only arguably of considerable empirical relevance, but also has some major advantages in allowing us to interpret the data. Nonetheless, however convenient it may be to assume that relative wages are fixed, this is obviously not true for all OECD nations. This analysis is therefore followed by a more problematic attempt to assess the impact of developing country manufac- 
tures exports using an "American" approach, in which wages are flexible.

\section{The Growth of World Trade: An Overview}

It is a late-twentieth-century conceit that we invented the global economy just yesterday. In fact, world markets achieved an impressive degree of integration during the second half of the nineteenth century. Indeed, if one wants a specific date for the beginning of a truly global economy, one might well choose 1869 , the year in which both the Suez Canal and the Union Pacific railroad were completed. By the eve of the First World War steamships and railroads had created markets for standardized commodities, like wheat and wool, that were fully global in their reach. Even the global flow of information was better than modern observers, focused on electronic technology, tend to realize: the first submarine telegraph cable was laid under the Atlantic in 1858, and by 1900 all of the world's major economic regions could effectively communicate instantaneously. How has world trade evolved since that impressive beginning, and what aspects of the current growth in world trade are truly new?

\section{Trade as a Share of Output: A Long-term Perspective}

Although the volume of world trade has been marked by a steady upward trend since about 1950, a longer-term perspective reveals that such growing integration is by no means necessary. On the contrary, between 1913 and the early post-World War II years most of the world's economies turned inward, and the share of world output that entered into international trade declined substantially. Much of the growth in trade since 1950 therefore simply represents simply a recovery to former levels. Indeed, to the extent that it is possible to make comparisons, world trade as a share of world output does not seem to have recovered to its 1913 level until sometime in the mid-1970s; only the growth since then truly represents a new degree of integration.

Tables 1 and 2 show some indicative numbers. Table 1, derived from data assembled by the World Bank, shows estimates of merchandise trade as a share of world output since the middle of the nineteenth cen- 
Table 1. World Merchandise Exports as Percentage of GDP

Percent

\begin{tabular}{lllllll}
\hline 1850 & 1880 & 1913 & 1950 & 1973 & 1985 & 1993 \\
\hline $5.1^{\mathrm{a}}$ & $9.8^{\mathrm{a}}$ & $11.9^{\mathrm{a}}$ & 7.1 & 11.7 & 14.5 & 17.1 \\
\hline
\end{tabular}

Source: World Bank, (1995).

a. OECD countries only.

Table 2. Trade Shares in the United Kingdom, the United States, and Germany

Percent $^{\mathrm{a}}$

\begin{tabular}{lrrrr}
\hline Country & 1913 & 1950 & 1970 & 1987 \\
\hline United Kingdom & 27.7 & 13.1 & 16.6 & 21.1 \\
United States & 3.9 & 2.9 & 4.4 & 7.4 \\
Germany & 19.9 & 9.8 & 17.4 & 23.3 \\
\hline
\end{tabular}

Source: Liesner (1989).

a. Merchandise trade, measured as the average of exports and imports, as a share of GDP.

tury. ${ }^{2}$ The data show a marked increase in trade up to 1913; a substantial dropoff by 1950; and a recovery that has continued to the present, finally outstripping 1913 levels sometime between 1973 and 1985.

Table 2 shows merchandise trade, measured as the average of exports and imports, as a share of GDP for three major economies since 1913. All three show the same pattern of dip and subsequent rise. Although the United States had a slightly larger trade share in 1970 than in 1913, the United Kingdom and Germany were still below their 1913 trade levels; the general picture of world integration that did not exceed earlytwentieth-century levels until sometime well into the 1970s is thus broadly confirmed.

In the last decade or so, the share of trade in world output has finally reached a level that is noticeably above its former peak. Nonetheless, it would be hard to argue that the sheer volume of trade is now at a level that marks a qualitative difference from previous experience. The United States, in particular, remains considerably less dependent on trade than major European countries have been for at least a century.

Does this mean, then, that there is nothing new about the kind of growth of world trade that has taken place over the last generation? No: while the overall volume of trade has not increased as much as might

2. Unfortunately, the pre-World War I data are only for OECD countries. 
be expected, the aggregates conceal several novel features of modern international trade.

\section{New Aspects of Trade}

It is possible to identify at least four new aspects of modern world trade-new in the sense that they did not have counterparts in the previous golden age of the global economy. These are the rise of intra-trade, trade in similar goods between similar countries; the ability of producers to slice up the value chain, breaking a production process into many geographically separated steps; the resulting emergence of supertraders, countries with extremely high ratios of trade to GDP; and, the novelty that provokes the most anxiety, the emergence of large exports of manufactured goods from low-wage to high-wage nations.

INTRA-TRADE. As already pointed out, the United Kingdom has been a highly trade-dependent nation since the mid-nineteenth century; measured as a share of the United Kingdom's output, trade is basically no higher now than it was in the high Victorian period. There have, however, been some major changes in the composition of British trade, both by commodity and region. Table 3 provides indicative numbers comparing British trade in 1913 and 1992. They show that in 1913 Britain was, to a good approximation, a nation that exported manufactured goods and imported raw materials, period; and it was a country that largely traded with raw material producers overseas. By 1992 British imports as well as exports consisted largely of manufactured goods, and most of the country's trade was with other European nations - that is, with countries with similar resources. It is also true that a high proportion of the trade among industrial countries appears to consist of intra-industry trade, two-way trade in goods in the same commodity class. And it was

Table 3. Commodity and Geographical Composition of U.K. Trade Percent $^{\mathrm{a}}$

\begin{tabular}{ccccc}
\hline Year & $\begin{array}{c}\text { Exports of } \\
\text { manufactures }\end{array}$ & $\begin{array}{c}\text { Imports of } \\
\text { manufactures }\end{array}$ & $\begin{array}{c}\text { Exports to } \\
\text { Europe }\end{array}$ & $\begin{array}{c}\text { Imports from } \\
\text { Europe }\end{array}$ \\
\hline 1913 & 75.5 & 20.2 & 39.5 & 44.6 \\
1992 & 81.9 & 78.4 & 63.8 & 63.7 \\
\hline
\end{tabular}

Source: Mitchell (1988), Barraclough (1978), and Great Britain, Central Statistical Office (1994).

a. Numbers are percentages of the relevant piece of trade. Export columns indicate percentage of total merchandise exports; import columns indicate percentage of total merchandise imports. 
a striking feature of the growth in trade that followed major trade liberalizations among industrial countries, such as the formation of the EEC in 1958 and the United States-Canada auto pact in 1965, that the bulk of the increase in trade consisted of nearly balanced increases in exports and imports within three-digit industrial categories. ${ }^{3}$

It is probably fair to say that the standard explanation for trade in similar products among similar countries is that it is motivated by economies of scale in the production of differentiated products, although there remains some skepticism. ${ }^{4}$ The important point for current purposes, however, is that the rise of intra-trade depends on some ways in which the nature of "typical" manufactured products has changed since 1913. To put it briefly, manufactured goods today are more complex than those of our great-grandfathers' day; not only are they more finely differentiated, their manufacture involves the use of a much greater variety of specialized intermediate goods (and intra-industry trade consists largely of trade in such intermediates). Cotton textiles, the principal British export in the early stages of industrialization, were a fairly standardized product; one could not really imagine much two-way trade in bolts of cloth. Furthermore, production involved only a few steps, from raw cotton to yarn to cloth, leaving little scope for the vertical disintegration of the industry. By contrast, modern manufactures-take the overused but inevitable example of automobiles-are highly differentiated, and their production involves a number of different stages. If these stages take place in different countries, they become a source of increased trade volume; so that it is not surprising to see Germans driving Hondas while Japanese drive BMWs.

SLICING UP THE VALUE ADDED CHAIN. In Detroit's Institute of Fine Arts there is a remarkable room whose walls are painted with four stunning murals by Diego Rivera. The Rivera murals, completed in 1933, show in considerable detail the operations of Ford's River Rouge industrial complex - a giant facility that combined at a single site blast furnaces, rolling mills, engine casting, body stamping, and assembly of complete automobiles. The Rouge plant was, in effect, a facility that ingested coke and iron ore at one end and extruded passenger cars from the other.

Although Rivera's murals were intended as a celebration of the power

3. See, in particular, the papers by Grubel (1967) and Balassa (1966).

4. The canonical reference is Helpman and Krugman (1985). 
of modern industry (and also, to his patron's dismay, a condemnation of its brutality), they now have a decidedly archaic feel. Part of that sense of old-fashioned industry comes from the very degree of integration that seemed so impressive at the time. What are all those disparate operations doing in the same facility? Why are they not being done at specialized plants scattered around the globe?

It would be interesting to know how many facilities the average iron atom in a 1995 Ford automobile has passed through (or better yet, to know how many miles it has traveled, from the time it enters the gate of the steel plant to the time it rolls off the assembly line). But it is generally believed (with little hard statistical evidence) that the trend in manufacturing has been to slice up the value chain-to produce a good in a number of stages in a number of locations, adding a little bit of value at each stage.

Such slicing up could greatly increase the potential volume of international trade. In 1913, a given consumer good could, to a rough approximation, be exported only once. Today it can be exported many times: a good that is produced in one country may be assembled from components produced in other countries, and these in turn may be assembled from subcomponents produced in yet other countries. As a result, the trade involved in the global production of a final good may easily be several times the value added in all stages of that production.

This increased potential for trade may help explain the next new aspect of world trade: the emergence of supertrading nations.

SUPERTRADING ECONOMIES. Global trade as a percentage of global output is, even now, only moderately higher than it was in 1913. The most trade-oriented economies, however, have much higher trade shares than ever seen before. As far as the available data indicate, there was no country in 1913 whose exports exceeded 50 percent of GDP. Today there are at least six such countries: ${ }^{5}$

Exports as percentage

of GDP, 1990

Singapore

174

Hong Kong

144

Malaysia

78

5. World Bank (1994). 
$\begin{array}{ll}\text { Belgium } & 70 \\ \text { Ireland } & 64 \\ \text { Netherlands } & 52\end{array}$

The emergence of supertrading economies clearly depends on the ability of modern industry to slice up the value chain, so that the value of exports can be substantially larger than the value added in the export industry. This is a fortiori true for Singapore and Hong Kong, where exports actually exceed GDP (alias, value added in the domestic economy). But it must also be true for all the other countries shown, since it is virtually certain that at least 60 percent of the employment and value added even in small countries is generated in nontradable sectors; thus a trade share of much more than 30-40 percent can only arise when exports involve adding a fairly small amount of value to imported intermediate goods.

Of the countries listed above, Belgium and the Netherlands represent something of a special case. They are best thought of as part of an integrated economic region that comprises northern France and, most important, the Ruhr and nearby areas of Germany; different pieces of a productive process tend to be spread across this region in much the same way that manufacturing plants in the modern U.S. automobile industry tend to be scattered across a fairly wide area of the Midwest.

The other countries in the supertrader class, however, represent something different: they are all low-wage manufacturing platforms. That is, they are locations to which semifinished products are sent to have labor-intensive operations performed on them, and from there shipped on for further work. Ireland, where wages are high by Chinese standards but low by European standards, plays this role on a local basis; the Asian supertraders play this role globally.

One of the effects of the sliced-up value chain in world trade has been to weaken the traditional link between the population of a country and its trade share. There is still a strong inverse correlation: it is no accident that the United States has a lower trade share than any other advanced nation, or that Japan has the second lowest. But in 1990 Belgium, with almost ten million people, had a trade share twice that of Iceland, with only 255,000 . The point is that Iceland is not, like Belgium, situated squarely in the middle of an industrial complex; and Iceland's relatively high wages, supported by fish exports, ruled it out as a manufacturing 
platform along the lines of Ireland (although Reykjavik and Cork are approximately the same shipping distance from Rotterdam).

LOW-WAGE MANUFACTURING EXPORTERS. Finally, the novel aspect of trade that has created the most controversy and concern is the rapid growth of manufactured exports from low-wage, newly industrializing economies (NIEs).

It seems likely that the rise of NIE exports has something to do with the slicing up of the value chain. In the early stages of the NIE phenomenon, when rapid growth was limited to the Asian "tiger" economies, it was common to hear doubts expressed about the possibilities for such growth on a really large scale. Surely a second wave of manufacturing exporters would soon be competing for the same limited markets-apparel, toys, and a few other labor-intensive goods-that were being served by the "Gang of Four"? And surely there would be an insufficient range of suitable products to allow rapid growth of manufactured exports from, to take an unlikely candidate, mainland China!

What has happened, however, is that it has proved possible to find expanded niches for labor-intensive production by slicing up the production of goods traditionally viewed as skill-, capital-, or technologyintensive and putting the labor-intensive slices in low-wage locations. To take what has become a classic example, a notebook computer looks like a high-technology product; but while the American microprocessor and the Japanese flat-panel display are indeed high-tech, the plastic shell that surrounds them and the wiring that connects them are not, so the assembly of notebook computers becomes an NIE industry.

Incidentally, the effect of the sliced-up value chain on low-wage exports is one area in which the conventional wisdom among business writers seems to be precisely wrong. It is often said that labor costs are now such a low share of total costs that low wages cannot be a significant competitive advantage. But when businesspeople say this, they do not mean that labor costs have declined as a share of value added: on the contrary, the division of value added between capital and labor has been impressively stable over time. What they mean, instead, is that because of the growing vertical disintegration of industry the value added by a given manufacturing facility is likely to be only a small fraction of the value of its shipments; and thus the labor share of that value added is also a small fraction of costs, which are dominated by the cost of intermediate inputs. But this vertical disintegration, or slicing up of the value 
Table 4. Exports of Manufactured Goods from Newly Industrializing Economies Percentage of GDP in destination

\begin{tabular}{cccc}
\hline Year & $\begin{array}{c}\text { All industrial } \\
\text { economies }\end{array}$ & European Union & United States \\
\hline 1970 & 0.24 & 0.22 & 0.28 \\
1990 & 1.61 & 1.30 & 1.91 \\
\hline
\end{tabular}

Source: Exports from UNCTAD (1994); GDP from OECD, National Accounts.

chain, creates a greater, not a smaller opportunity to relocate production to low-wage locations.

The reasons for the explosion of exports and more generally of economic growth in NIEs are deep and deeply disputed questions. What is clear, however, is that NIE export of manufactures, a phenomenon that was essentially nonexistent twenty-five years ago, has become a significant feature of the world economy. Table 4 shows the growth of manufactures exports from the NIEs, measured as a share of advanced country GDP. In addition to showing that these exports have effectively emerged out of nowhere, the table also makes the point that they are still not very large as a share of total OECD spending.

\section{Why Has World Trade Grown?}

When economic commentators try to explain why world trade has grown faster than world output, they generally offer one of two explanations. The explanation most popular with journalists stresses the effects of technology: Lower costs of transportation and the growing speed of communications have made the world a smaller place. International economists, while paying some attention to this explanation, tend to stress political factors to at least an equal extent; they point to the role of the GATT and, more recently, of unilateral liberalizing measures by developing countries. It is also important to realize that the volume of international trade depends to some degree on how boundaries are drawn-for any given geography of world production, the measured volume of international trade will depend on which shipments are defined as international, and so some of the apparent change in world trade may simply represent changes in these definitions. 


\section{Political Factors}

It is difficult to quantify protectionism. Tariff rates can be measured, although there is still a problem of interpreting ex post data: to take the extreme case, a country that imposes prohibitive tariffs on some goods may have a low tariff rate on all of the goods it continues to import. Nonetheless, there is no question that the general profile of world protectionism since the early twentieth century has been the inverse of that of world trade: during the interwar period there was a proliferation of tariffs, import quotas, and exchange controls; from World War II onward there has been a general trend toward freer trade. The correspondence between the time profile of trade policy and that of trade shares is prima facie evidence that political factors have played a major, perhaps dominant role in the growth of world trade since 1950. In fact, a firstpass story about the growth of world trade might run as follows: the key technologies that created a global economy were the railroad, the steamship, and the telegraph. Everything since then has represented only a marginal improvement. Thus very large-scale world trade emerged in the days of the Pax Britannica. Politics then killed that first global economy; with the gradual restoration of a relatively free trade environment under the Pax Americana, the global economy was gradually reconstructed, and the world economy more or less reached its previous level of integration by 1980 .

It is possible to elaborate on this story in several ways. First, it is worth pointing out that the pre-World War I world economy was not exactly characterized by free trade. Indeed, the two largest economies, the United States and Germany, were frankly protectionist. Thus it should not be surprising that the closer approximation to free trade that has been achieved in recent years has brought world trade somewhat above early-twentieth-century levels, nor that-as shown in table 2the once-protectionist United States and Germany now have noticeably larger trade shares than they did in 1913, while then-free-trading Britain does not.

Second, it is important to be aware that the progress toward free trade in the postwar period has not entirely taken place through GATT negotiations, nor for that matter among the OECD countries. In recent years the most important moves toward free trade have been unilateral actions by developing countries, many of which have turned away from the im- 
port-substitution policies of the past. Such moves do not only affect the developing countries: because trade liberalization increases exports as well as imports, the move to free trade in the developing world contributes to the growth of developing country exports to the high-wage nations.

Finally, there is scattered but suggestive evidence that removing formal barriers to trade is not enough to produce full economic integration. An intriguing study by John McCallum of the Royal Bank of Canada, using data from the 1988 input-output tables for Canada, finds that Canadian provinces traded far more with each other than they did with American states of comparable population and at comparable distances. ${ }^{6}$ Thus Ontario exported more than three times as much to British Columbia, with three million people, as it did to California, with almost thirty million. When McCallum estimated a gravity equation (see below) for trade among Canadian provinces and U.S. states, he found that intraCanadian trade was a startling twenty times as large as would have otherwise been expected. What is so dramatic about these findings is that, although the data predate the Canada-United States Free Trade Agreement, tariff barriers were already very low in 1988; and the linguistic divide in North America runs through the middle of Canada, not between Canada and America. Thus this evidence suggests that political boundaries, even between friendly nations that speak the same language, can be serious obstacles to trade. And it therefore helps to confirm the belief, which underlies such initiatives as "1992" in Europe, that there remains substantial room for policy moves to expand international trade through a process of harmonization of laws and institutions. (Robert Lawrence has dubbed such moves "deep integration.”)

\section{Boundary Issues}

McCallum's results on intra- versus extra-Canadian trade notwithstanding, it is sometimes useful to think about world trade by imagining that it were possible to take a given geography of world production and transportation and then draw arbitrary lines on the map called national borders without affecting the underlying economic geography. If international trade only includes shipments that cross the borders, it is clear

6. McCallum (1995). 
that the volume of that trade will depend quite a lot on where one draws the lines.

A case in point is the trade of European Union countries. Taken individually, they are very open economies, with an average trade share of 28.0 percent in 1990 . However, more than 60 percent of their merchandise trade is with each other. If the European Union is taken as a unit, its merchandise trade with the external world is only 9 percent of GDP, not much more than that of the United States. ${ }^{7}$

There has been a fair amount of literal redrawing of boundaries in the last few years. More important for world trade, however, has been the changing distribution of world output among existing nations. To see why this matters, compare the likely share of trade in world output in two hypothetical cases: a world of two equal-size countries, and one in which the larger country has 95 percent of gross world product. It seems obvious that in the latter case the trade share would be much smaller.

This idea can be formalized if we suppose that world trade can be described by a simple gravity equation. Gravity equations attempt, with considerable success, to explain the volume of trade between any pair of countries with a few variables, usually the GDPs of the countries and the distance between them. A typical gravity equation is of the form

$$
T_{i j}=k Y_{i}^{\alpha} Y_{j}^{\beta} D_{i j}^{-\gamma},
$$

where $T_{i j}$ is the trade between two countries, $i$ and $j ; Y_{i}$ and $Y_{j}$ are the GDP of countries $i$ and $j$, respectively; $D_{i j}$ is the distance between the two countries; and $k$ is a parameter. In practice such equations typically find the exponents on GDP to be less than one, and a surprisingly strong effect of distance. ${ }^{8}$ But in an idealized world in which a buyer is equally likely, when buying a traded good, to buy it from a supplier anywhere in the world, $\alpha=\beta=1$, and $\gamma=0$. And then two results follow. The share of trade in the GDP of any one country would be

$$
\frac{T_{i}}{Y_{i}}=k\left(1-s_{i}\right),
$$

where $s_{i}$ is that country's share in gross world product; and the share of trade in that gross world product would be

7. There are no reliable estimates of the direction of service exports. OECD (1992) has data on trade shares. Data on merchandise trade by location from European Economy.

8. For some recent estimates, see Frankel, Wei, and Stein (1994). 


$$
\frac{T_{W}}{Y_{W}}=k\left(1-\sum s_{i}^{2}\right)
$$

In other words, an individual country's trade would be larger, the smaller its share of world income; and the overall share of trade in the world would be larger, the more equal in size its national economies. In actual fact, the national distribution of gross product among the world's economies, as measured at nominal exchange rates, has become somewhat more equal over time: the sum of squared shares fell from 0.130 in 1960 to 0.104 in 1993. Or, inverting the ratio, the number of countryequivalents in the world economy has risen from 7.7 to 9.6. The most important source of this rise has been the relative decline of the United States, from 31.6 percent of the gross product of market economies in 1970 , to 25.6 percent in $1993 .{ }^{9}$ This may well explain why the rise in the trade share has been more dramatic for the United States than for other industrial countries: indeed, comparing the present situation with that in the 1950s, it may be said that the United States used to trade with a world that in economic terms was barely larger than itself, but now trades with a world three times its size.

\section{Technological Change}

It is clear that the volume of world trade is not completely determined by technology: transportation and communication technology were considerably better in 1950 than they were in 1913, but the world economy was substantially less integrated. Correspondingly, since much of the growth of trade since then represents only a return to 1913 levels of integration, it is hard to argue that technology has been the dominant factor in that growth. Indeed, it is possible to make a strong antitechnology case: Granted that there have been reductions in transport cost and improvements in the speed and bandwidth of communications, surely these are marginal improvements on a set of technologies that already permitted massive long-range trade? ${ }^{10}$

9. United Nations (1993).

10. It is worth pointing out, however, that transportation technology in 1995 should not be compared with that in 1950, but rather with the technology of 1913. Presumably there was a rise in potential trade during the interwar period, which was suppressed by political factors and could only manifest itself once a liberal trade regime was reestablished. 
The case for the important role of technology must rest on more subtle indicators than the aggregate volume of trade. One indicator is the emergence of new aspects of trade, especially those associated with the thinner slicing of the value chain. Arguably, before the widespread availability of computers and telecommunications, the geographic dispersion of a complex production process was too hard to coordinate. (Even now, the adoption of just-in-time production techniques is usually associated with geographic clustering of production.)

Some support for this view is given, in an indirect way, by estimated gravity equations. These always show a strong effect of distance on trade volumes, which is both too large and of the wrong form to be easily associated with measured transport costs. While it is not clear why distance plays so strong a role in trade, a common guess is that it proxies for the possibilities of personal contact between managers, customers, and so on; that much business depends on the ability to exchange more information, of a less formal kind, than can be sent over a wire. If this is true, then we might argue that the advent of such innovations as longrange passenger jets, cheap intercontinental telephone calls, fax machines, and electronic mail permit an intensity of long-distance business relationships that was not possible in 1913. Steamships may have been quite efficient at transporting bulk commodities, but they were too slow to allow regular visits to headquarters; telegraphs may have allowed effectively instantaneous communication of futures prices and interest rates, but they lacked the bandwidth to allow the home office to transmit detailed production specifications and the factory to explain why they would not work.

A final point. There is one aspect of technological progress that has acted to reduce the share of trade in world output: the faster rate of productivity growth in the production of goods than that in services. The declining relative productivity of the service sector is, according to most estimates, the main reason why that sector constitutes a growing share of the errployment and value added in advanced economies (that is, the elasticity of substitution between services and goods appears to be low, so a rising relative price translates into a rising share in the economy). ${ }^{11}$ Despite some recent growth in service trade, services are by and large still nontradable. Thus although it has become easier and cheaper to 
trade whatever can be traded, a declining share of the economy consists of tradable goods and services.

\section{A Stylized Model of Global Trade, Employment, and Wages}

So far this paper has described the growth of world trade and reviewed some possible explanations for that growth. The time has now come to try to understand the effects of growing trade-bearing in mind that trade flows cannot be taken as wholly exogenous, but must be viewed as part of a system in which they, along with a number of other things, are jointly determined.

What effects of growing trade should be the subject of analysis? It is a bad idea to try to discuss everything that might occur because of international integration, all at once. A broad-brush approach may be acceptable when offering a descriptive survey, but to assess the effects of trade one needs to create a model; and if the model is to be tractable and comprehensible, it must focus on only a few things.

The focus here will be dictated by political controversy. Of the new aspects of world trade discussed above, the rise of intra-trade has generally been viewed as benign, and the slicing up of the value chain and the emergence of supertrading nations have excited interest but little controversy. The controversial new aspect of international trade is the rise of manufacturing exports from newly industrializing economies.

The rapid growth of NIE exports has more or less coincided with some disturbing trends in OECD labor markets: a sharp rise in wage inequality (especially in the United States) and a sharp rise in unemployment (mainly in Europe). It is widely believed that the unfavorable labor market trends and the growth of NIE trade are connected.

This belief has been expressed at greatly varying levels of sophistication. At one end, there is the phenomenon of a self-made billionaireturned-politician, who has declared himself an expert on economics and launched a campaign to warn his countrymen of the impoverishment they face as a result of free trade with low-wage nations. I refer, of course, to Sir James Goldsmith, whose book The Trap has been a European best-seller. While one might dismiss Sir James and his untitled Texan counterpart as marginal, milder versions of the same warning are found among highly respected and influential people. Even the Euro- 
pean Commission, in its 1993 White Paper Growth, Competitiveness, Employment, attributed a major share of the rise in European unemployment rates to the fact that "other countries are becoming industrialized and competing with us-even on our own markets-at cost levels which we simply cannot match."12

Academic research has been far less supportive of the claim that NIE manufactures exports are a major source of problems in OECD labor markets. While there are some studies that do claim to find evidence for substantial pressure from low-wage imports on unskilled labor in advanced countries, it is probably fair to say that a preponderance of the research to date suggests that the impact of third world exports on first world labor markets has been small, or at least elusive. ${ }^{13}$

One thing that is conspicuously lacking in the literature to date, however, is a consistent picture of the interaction between labor market developments in the high-wage countries and the growth of exports from the low-wage countries. While some (though not all) of the studies are based on a consistent underlying model of employment and wages in the advanced countries, there does not seem to be any effort to show how wages and employment in the advanced countries, and trade with the third world might be simultaneously determined. That is, there do not seem to be any complete general-equilibrium stories out there.

In the remainder of this paper I will try to fill that gap, by developing a highly stylized model of global trade, employment, and wages. This model simplifies reality too much to be estimated with or even calibrated to the data. It is possible, however, to use the results of other peoples' empirical work to assign a set of ballpark parameters to the model, allowing what amount to glorified back-of-the-envelope estimates of the impact of growing NIE trade.

\section{Structure of the Model}

In order to focus on the effects of NIE trade in manufactured goods, I assume a world consisting of only two economies: one that is intended to represent the OECD as a whole, the other to represent the aggregate

12. Commission of the European Communities (1993, p.4).

13. See, in particular, Wood (1994) and Leamer $(1993,1994)$ in support of the adverse effects of NIE exports, and Katz (1992), Bhagwati and Kosters (1994), and Sachs and Shatz (1994) for the alternative view. 
of NIEs. All transactions within each aggregate are ignored, as is the existence of other types of countries, like oil exporters.

The aggregate OECD is assumed to produce and consume two goods, 1 and 2, with production of good 1 being skill-intensive. Demand is determined by a utility function in the consumption of goods 1 and 2 ,

$$
U=U\left(C_{1}, C_{2}\right) .
$$

It will be convenient to assume that tastes are homothetic, so that marginal and average spending have the same composition.

Since the focus of this analysis is on labor market developments in the OECD, it is necessary to have some explicit treatment of the factor markets. I will make several strategic simplifications. First, the only productive inputs will be skilled labor $\left(L_{S}\right)$ and unskilled labor $\left(L_{U}\right)$; capital will be left out of the story. The main reason for doing this is that the distribution of income between capital and labor has neither changed a lot nor been a major source of controversy in the last two decades; the share of labor compensation in U.S. national income, for example, has barely changed, actually rising from 73 to 74 percent between 1973 and 1993. It is not clear that this is what one would have expected a priori, nor is it clear that capital will remain a sort of bystander factor indefinitely. For the purposes of this model, however, all income will be assumed to accrue either to skilled or to unskilled labor.

Second, production, $Q$, will be assumed to take place under constant returns to scale, with the production functions

$$
Q_{1}=F\left(L_{S 1}, L_{U 1}\right)
$$

and

$$
Q_{2}=G\left(L_{S 2}, L_{U 2}\right) .
$$

Economies of scale are widely believed to be important in understanding both the causes and effects of trade within the OECD, but probably play a smaller role in NIE trade.

For the same reason, markets are assumed to be perfectly competitive. This is likely to raise some stronger objections. One common story about the effects of international trade on wages is that it has weakened the bargaining power of workers; this only makes sense if workers and employers are struggling over the division of some rent, presumably created by the market power of the firm. It is arguable whether such stories 
can be a large part of the picture: they seem to predict a shift in the distribution of income between capital and labor, which has not happened, rather than between different types of labor, which has; and they apply only to those workers in traded-goods industries, whereas the rise in income inequality has been pervasive throughout the economy. In any case, for this model competition is assumed to be perfect.

The OECD's trade is the difference between its production and its consumption. Exports of the skill-intensive good, $X_{1}$, and imports of the less skill-intensive good, $M_{2}$, can be written as

$$
X_{1}=Q_{1}-C_{1}
$$

and

$$
M_{2}=C_{2}-Q_{2} .
$$

How should the OECD's trade with the NIEs be modeled? It is common in trade theory to work with small economies that face given world prices; and some writers on the effects of changing world trade still use this assumption. For the OECD as a whole, however, this is a deeply unrealistic assumption; worse yet, it is analytically awkward, leading to excessively "bang-bang" solutions in some cases. It thus makes sense to regard the OECD as having substantial market power relative to the NIEs. This can be represented by assuming that the OECD faces a restof-world offer curve,

$$
M_{2}=T\left(X_{1}\right) .
$$

I will not make any attempt to model the inside workings of the newly industrializing countries; they will simply be summarized by the offer curve given by equation 9 . The growth and increased integration of the NIEs with the world economy are then captured simply by an outward shift in that offer curve. In fact, since their manufactured exports were negligible in 1970, the effects of their emergence can be approximated by contrasting an initial period in which the OECD has no external trade with a subsequent period in which it faces an offer curve that leads to the observed trade volumes. That is, the model analyzes the effects of globalization by contrasting the current situation with one of autarky for the OECD as a whole.

That is the whole theoretical model. Before assigning ballpark parameter values, it may be useful to review some of the key mechanics of $2 \times 2$ production models. 
Figure 1. Relationship between Goods Prices, Factor Prices, and Factor Proportions

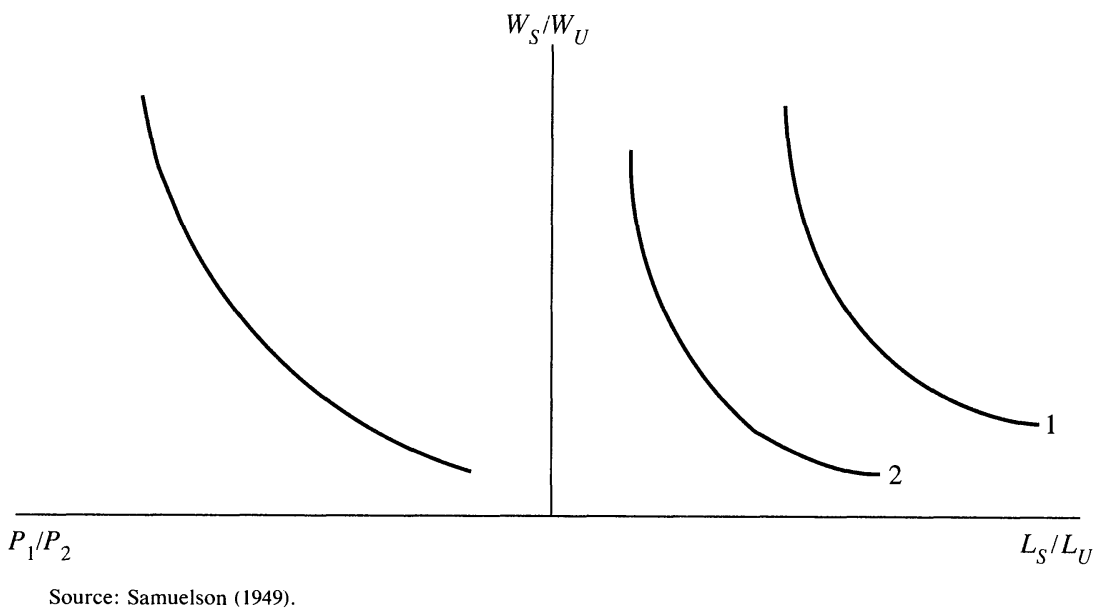

The most important relationships are presented in figure 1, which reproduces the familiar diagram introduced by Paul Samuelson. ${ }^{14}$ Figure 1 summarizes the three-way relationship between goods prices, factor prices, and factor proportions. The right panel shows that given the ratio of skilled to unskilled wages $\left(W_{S} / W_{U}\right)$, each industry chooses a ratio of skilled to unskilled workers in production. The left panel shows the basic Stolper-Samuelson relationship between the relative price of the skill-intensive good $\left(P_{1} / P_{2}\right)$ and the relative wage of skilled workers that prevails if both goods are produced.

\section{Putting Numbers to the Model}

Quantifying a model like this poses certain conceptual problems. That is a polite way of saying that it is somewhat difficult to know exactly how to assign numbers to a model that is, in important respects, blatantly untrue. Not only are there more than two kinds of labor, other factors besides labor, other regions besides the OECD and the NIEs; it is not even true that workers of apparently similar skill receive the same wages in exporting and import-competing sectors. Yet for the model to be used, it is necessary to assign a set of parameter values that fit together.

14. See Samuelson (1949). 
The following parameters are used in the trade model of the next two sections:

Initial ratio of skilled to unskilled wages $\quad 2$

Share of skilled workers in industry 1 employment $\quad 0.5$

Share of skilled workers in industry 2 employment $\quad 0.2$

Share of skilled workers in labor force $\quad 0.4$

Share of wages of skilled workers in industry $\quad 2 / 3$

1 value added

Share of wages of skilled workers in industry $\quad 1 / 3$

2 value added

Share of good 1 in total expenditure $\quad 5 / 7$

-Wage ratio. Adrian Wood, using his definitions, finds a wage ratio between skilled and unskilled workers in the North of $2.08 .{ }^{15}$ I round this to 2 .

-Employment share in industry 1. Wood also estimates a share of skilled employment in export-oriented manufacturing of 50.24 percent, which I round to $50 .{ }^{16}$

-Employment share in industry 2. Wood does not, for reasons explained below, estimate the employment composition of Northern import-competing production. Other sources, using different definitions, have produced estimates. However, in order to make the model internally consistent, one must meet a constraint that is not met in the actual data: the difference in average wages between export and import-competing industries must be fully accounted for by the difference in skill composition. Bela Balassa found that wages in U.S. industries that export to developing countries were 28 percent higher than those in industries competing with imports from those countries; by assigning the import-competing industry a 20 percent skill fraction, I get an implied 25 percent average wage ratio, which seems close enough. ${ }^{17}$

-Labor supplies. If the OECD is producing both goods, the ratio of skilled to unskilled workers in the labor force must be between the ratios in the two industries. The choice of 40 percent skilled workers is arbitrary, but has little effect on the results below.

15. Wood (1994, p.403).

16. Wood (1994, p.403).

17. Balassa (1979). 
-Remaining entries. These follow from the previous numbers. In particular, the share of industry 1 in expenditure is determined by the requirement that the derived demand for factors equal the supply.

This completes the stylized model of the interaction between NIE trade and OECD labor markets, together with some semirealistic numbers that will allow back-of-the-envelope estimates of effects. The next step is to apply the model under two alternative assumptions about OECD labor markets.

\section{The Impact of Low-Wage Exports: A "European" Approach}

Most analyses of the impact of NIE trade have had an "American" flavor, in at least two senses. First, they tend to be based on U.S. data. Second, to the extent that they try to make an explicit estimate of the labor market effects, they assume that relative wages are flexible, and thus that any adverse impact on unskilled workers is reflected in declining wages rather than increased unemployment. This is a reasonable assumption for the United States, where low real minimum wages, weak unions, and a very weak social safety net give real wages for unskilled workers an impressive ability to decline. The European economy, however, which is roughly comparable to that of America in output and employment, presents a very different picture. Wage inequality has not increased to anything like the same extent; meanwhile, unemployment has risen from less than 3 percent at the beginning of the 1970s to double digits today.

This in itself would suggest that it is worthwhile to look at the impact of integration under "European" assumptions, with relative wages rigid and the consequent reduced demand for less skilled workers reflected in unemployment. In addition, however, the European version of the story is revealing in other ways: it highlights the importance of a general-equilibrium approach, and (as the next section shows) there are some surprising quantitative contrasts between the effects of trade in a "Europeanized" and an "Americanized" model.

For the moment, then, assume that $w_{S} / w_{U}$ is fixed, so that any pressure on labor demand is reflected in employment rather than wages; and suppose that a previously autarkic OECD economy is now presented with an offer curve from a group of newly industrialized economies, which allows the OECD to export good 1 and import good 2 . 
Figure 2. Adjustment of OECD Employment under the "European" Model

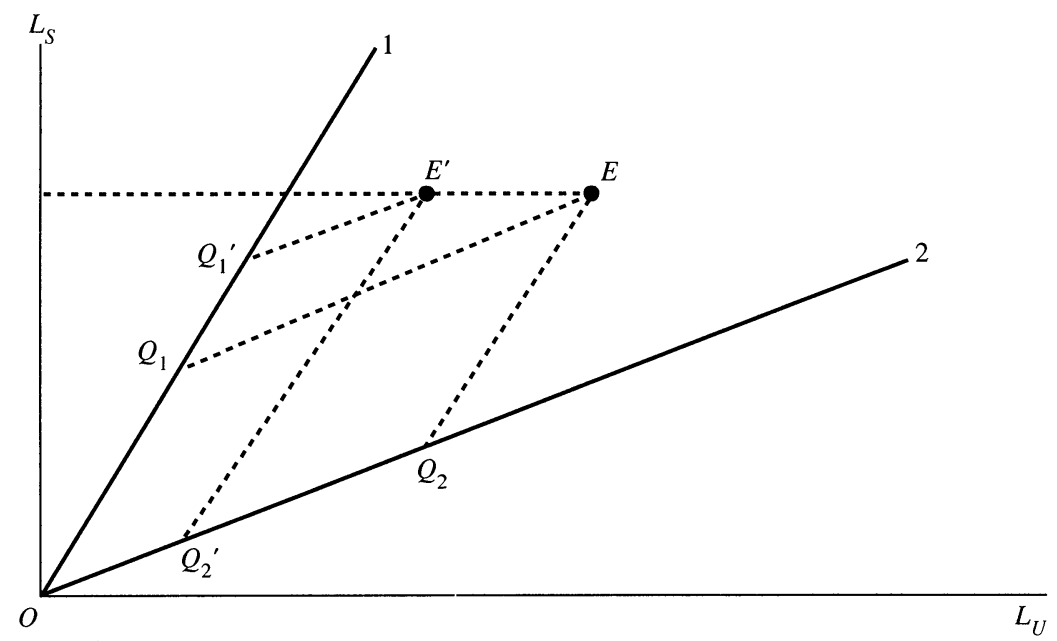

Source: Author's model as described in text.

The consequences may be analyzed in stages ${ }^{18}$ First, note that with rigid relative wages, the skilled-to-unskilled ratio in each industry is fixed. These ratios are illustrated by the slopes of rays 1 and 2 in figure 2 , which shows employment in the economy. The point $E$ represents the initial employment of the two factors. Since these levels of employment must be achieved using the factor proportions implied by the fixed relative wage, the resources employed in each industry are indicated by $Q_{1}$ and $Q_{2}$. Now suppose that there is a fall in the relative demand for the less skill-intensive good. This cannot be met by a change in relative wages, so it must be met with a reduction in unskilled employment. The employment point moves left to $E^{\prime}$. And output obeys the Rybczynski theorem: the resources devoted to industry 2 fall to $Q_{2}{ }^{\prime}$, while those devoted to industry 1 actually rise, to $Q_{1}{ }^{\prime}$.

Next, consider the implications for international trade. Figure 3 plots OECD exports against imports. Point $O$ represents autarky (no trade in manufactures with the NIEs), and slope of the ray $O A$ represents the relative price of good 1 in autarky. Now the NIEs arrive on the scene, with their presence summarized by the offer curve $O C$. What effect does this have on relative prices? As long as the OECD continues to produce

18. This analysis was inspired by and closely follows the analysis in Brecher (1974). 
Figure 3. Adjustment of OECD Exports and Imports under the "European" Model

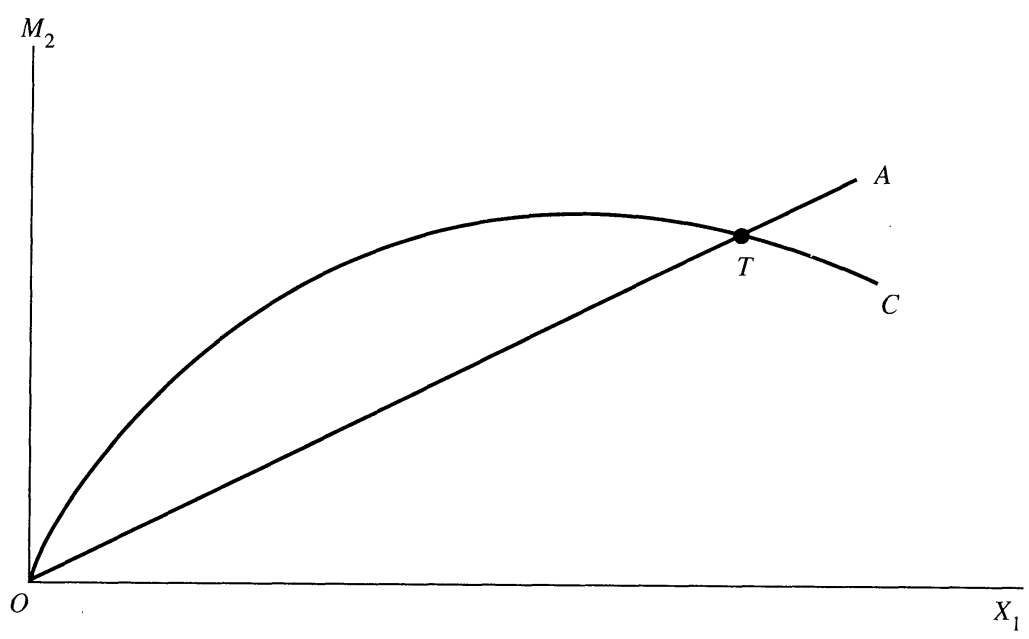

Source: Author's model as described in text.

both goods, it has no effect: the fixed relative wage ties down the relative price, according to the relationship in the left panel of figure 1. So the NIEs simply move along their offer curve to the point $T$, with $O T$ representing the volume of trade.

How does the emergence of this trade affect the OECD economy? It must be accommodated by changes in both production and employment, changes that involve demand as well as supply and even a sort of multiplier effect. The somewhat surprising logic of this response has not, to my knowledge, been traced out before; it is illustrated in figure 4 .

In this figure, the curve represents the production possibilities of the aggregated OECD economy, given the initial employment of both factors. The point $A$ is the equilibrium consumption and production of the economy in autarky - that is, before the NIEs arrive on the scene. Consumption at the relative prices indicated by the tangent budget line through $A$ will depend on income; the ray $O A$ represents the income expansion path.

Now the OECD opens trade with NIE economies that export good 2 and import good 1. If the OECD were a small, price-taking economy, it would completely cease production of good 2 . But because it is not, its production of 2 falls and its production of 1 rises, with an unchanged relative price, until the desired trade equals the amount of trade that the 
Figure 4. Adjustment of OECD Production and Consumption under the "European" Model

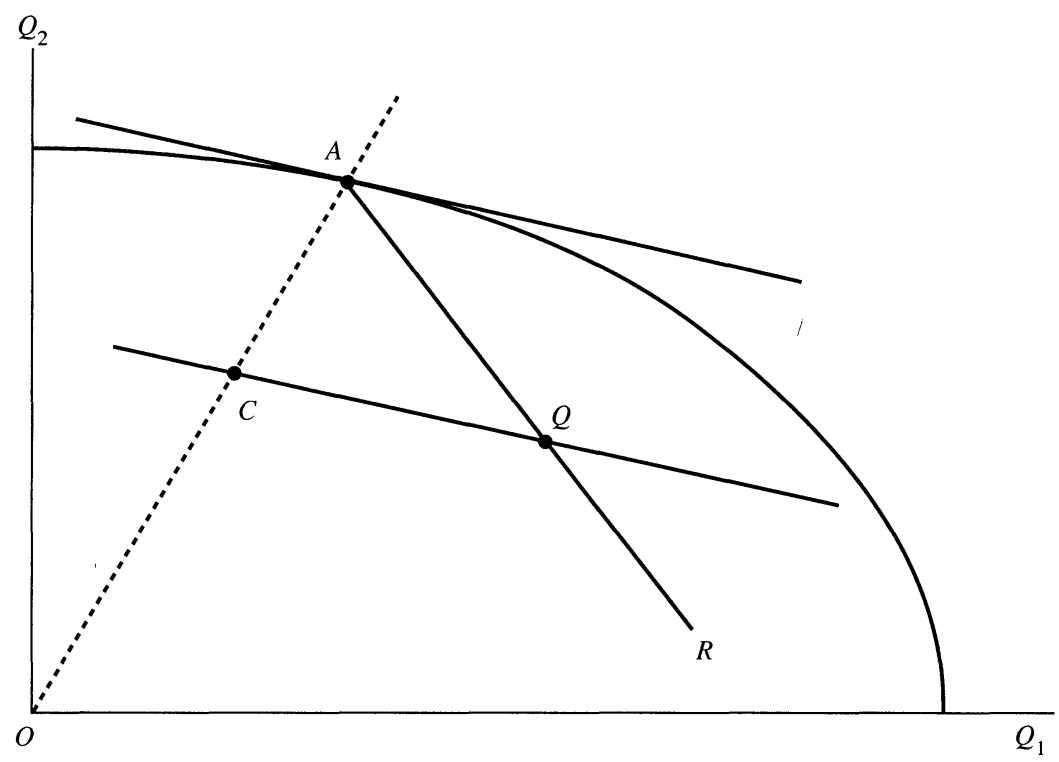

Source: Author's model as described in text.

NIEs are willing to do at that given relative price. Figure 4 shows that as employment of unskilled workers falls, the OECD's production moves down the "Rybczynski line" $A R$, which corresponds to the kind of adjustment in production shown in figure 2 . The value of production falls, and therefore the budget line shifts in; consumption therefore also moves down along the expansion path $O A$. Global trade equilibrium is reached when the OECD's desired trade vector $C Q$ is just equal to the NIE desired trade vector $O T$ in figure 3.

The opening of trade with the third world, then-given the assumption of rigid relative wages-leads to a fall in OECD employment. But how much of a fall? And how would one estimate the employment reduction in practice?

Interestingly, two popular calculations actually understate the employment effects of trade. One calculation involves looking at the total employment embodied in exports and imports. Since the average wage in export industries is, in fact, higher than that in import-competing industries, this approach seems to indicate that the number of jobs created 
Figure 5. Adjustment of OECD Employment and Consumption under the "European" Model

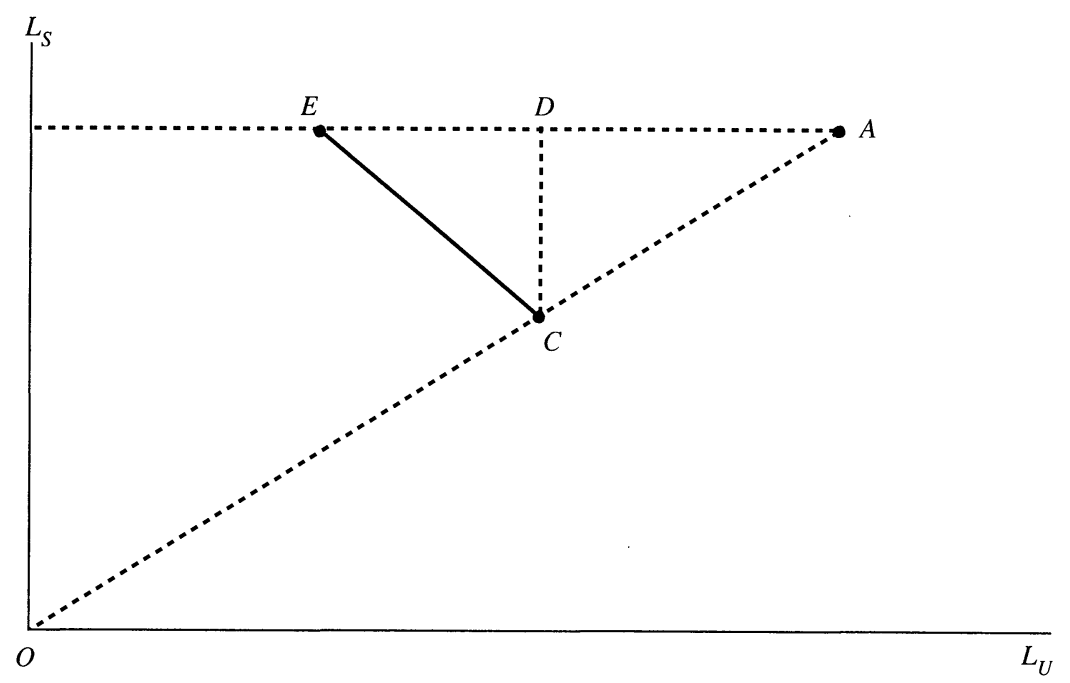

Source: Author's model as described in text.

by exports falls short of those displaced by imports. The other popular calculation involves looking only at the unskilled labor embodied in exports and imports, since it is among the unskilled that employment falls.

Both of these approaches, however, miss the point that as employment falls, so does income and hence domestic demand. It is clear from figure 4 that the output of good 1 rises by less than the volume of exports, and that the output of good 2 falls by more than the volume of imports.

How, then, can the employment effects of trade be determined? One way is to calculate the new equilibrium and grind out the implied employment change. There is, however, a shortcut that is possible because there is no change in relative wages (by assumption) or relative prices (by implication). That approach is illustrated in figure 5. As in figure 2, we show the factor content of output, with $A$ the initial employment. Figure 5, however, also shows OECD demand-the derived demand for factors embodied in production. In autarky this must be equal to the total supply. As income falls, this derived demand will fall along the expansion path $O A$. Meanwhile, employment of unskilled workers will fall to a point such as $E$. Through $E$, I have drawn a budget line, $E C$, whose slope is equal to $w_{S} / w_{U}$; employment and consumption of factors 
must both lie on such a line. Equilibrium involves a situation in which the production point, $E$, and the consumption point, $C$, are such that the implied trade in embodied factors, $E C$, equals the difference between the factors used to produce exports and those that would be needed to replace imports. ${ }^{19}$

It is immediately apparent that the decline in employment of unskilled labor is greater than the quantity of labor embodied in trade. The net "import" of unskilled labor is the distance $E D$, but the actual fall in employment is measured by the full distance $E A$.

\section{The Employment Effects of NIE Exports}

As figure 5 indicates, the effects of trade on employment in a rigidwage economy may be estimated from the factor content of trade, together with an estimate of the general-equilibrium multiplier effect. Specifically, the fall in employment is

\section{Net imports of unskilled labor + (Net exports of skilled labor $\times$ Unskilled-to-skilled ratio in OECD economy)}

Table 5 shows the results, using the World Bank's latest estimate of the share of NIE manufactures exports in OECD gross product and the parameters listed above.

This is a fairly large effect. It is still only a fraction of the actual rise in European unemployment, but it is far from negligible. And it therefore seems to suggest considerable reason for concern over the effects of low-wage manufactures exports on first world labor markets.

This fairly large estimate depends, however, on the assumption of rigidly fixed relative wages. Even in Europe, this is an exaggeration; and relative wages appear to be highly flexible in the United States. How do

19. The relevant factor content of trade here is that in OECD import-substituting production; the factors used to produce the goods in the third world are irrelevant. Wood (1994) has argued that developing countries produce "noncompeting goods" that are no longer produced in the high-wage nations, and that one must therefore try to estimate what it would have taken to produce these goods, rather than look at actual OECD industries. This assertion is, however, problematic. If these really are noncompeting goods, how can one assess their impact without specifying how they substitute in demand for other goods? After all, in a two-good model in which the OECD and the NIEs are specialized in producing different goods, an expansion of NIE exports would have no effect at all on equilibrium relative wages in the OECD. 
Table 5. Employment Effects of Trade under "European" Assumption Units as indicated

\begin{tabular}{ll}
\hline Manufactures imports $^{\mathrm{a}}$ & 1.75 \\
Net imports of unskilled labor & 0.82 \\
Net exports of skilled labor & 0.41 \\
Unskilled-to-skilled ratio in aggregate & 1.5 \\
$\quad$ employment & 1.43 \\
Fall in employment & \\
\hline
\end{tabular}

Source: Author's calculations based on model described in text and World Bank (1995).

a. Percentage of GDP.

b. Percentage of total employment.

c. Percent.

the results change if we "Americanize" the model, allowing wages to be flexible and therefore assuming that the effects of trade manifest themselves in income inequality rather than unemployment?

\section{The Impact of Low-Wage Exports: An “American” Model}

With full employment of both skilled and unskilled labor maintained by wage flexibility, the effects of opening trade between the OECD and the NIEs can be represented by a figure so familiar that Ronald Findlay has dubbed it the "sacred diagram" of international trade. Figure 6 shows how the pieces fit together when relative wages and hence prices can change. Point $A$, once again, represents OECD autarky. When trade is opened, the relative price of good 1 rises; the result is that production moves to $Q$, while consumption moves to $C$. If this is a global equilibrium, the NIE offer curve-drawn backward, with its origin at $Q$-must also pass through $C$, so that desired OECD exports equal desired NIE imports, and vice versa.

But how can we quantify this qualitative picture? At first, it might seem possible to begin in the same way as in the rigid-wage case, by calculating the factor content of trade; then asking how much these changes in effective supplies of skilled and unskilled labor affect relative wages, by making use of some estimated elasticity of substitution. This has in fact been the approach taken by some studies. ${ }^{20}$ Unfortunately, it runs into serious conceptual difficulties. Even the concept of net trade in em-

20. See, in particular, Borjas, Freeman, and Katz (1991). 
Figure 6. Adjustment of OECD Production and Consumption under the "American" Model

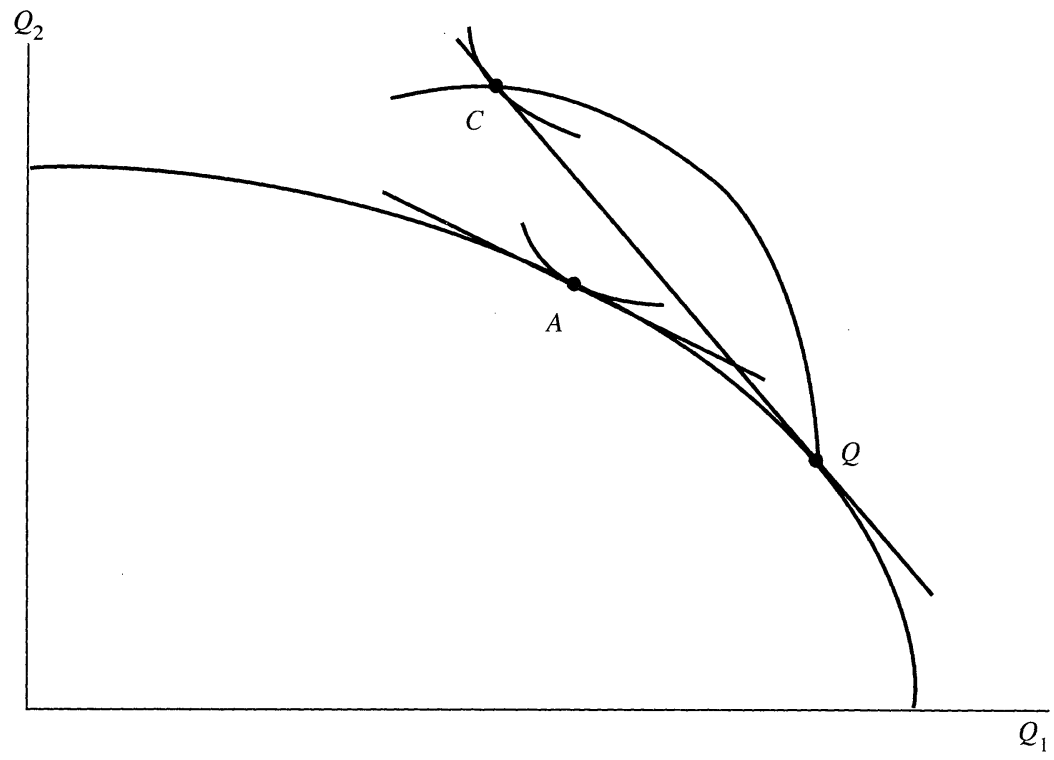

Source: Author's model as described in text.

bodied services become hard to make sense of when relative factor prices change as a result of trade; and the elasticity of substitution between skilled and unskilled labor will change when an economy is opened, if it has any meaning at all. (It is possible to rescue the concept if the economy does not face given world prices, but rather faces a concave foreign offer curve-and this is certainly true for the OECD as a whole. So one should not be as harsh in condemning studies that attempt to make inferences from the factor content of trade as some critics, such as Leamer, have been. ${ }^{21}$ )

Given these conceptual difficulties, several recent studies have attempted to infer the effects of trade on relative wages by looking at pieces of the mechanism by which the process should work. In particular, Robert Lawrence and Matthew Slaughter looked for evidence that the relative prices of less skill-intensive goods have indeed fallen, and that the industry mix within the United States has shifted toward skill-

21. See Leamer (1994). 
intensive sectors. ${ }^{22}$ They could not find any. A follow-up paper by Jeffrey Sachs and Howard Schatz did find some weak evidence for relative price changes in the expected direction, but nothing compelling. ${ }^{23}$

I offer here an alternative approach: with the addition of some further assumptions to the model already described, it turns into a tiny, computable general-equilibrium model of world trade. I can then ask the following question: What changes in relative wages and prices would be consistent with the observed growth of trade? The answer turns out to be surprisingly small-that is, the same model that predicts fairly large employment effects with rigid wages predicts quite small effects on relative wages when they are flexible.

\section{Making the Model Computable}

In order to make the model computable in the face of flexible prices and wages, it is necessary to specify elasticities of substitution in production and consumption-in effect, to choose functional forms. Since this is an illustrative exercise rather than a full-fledged CGE modeling project, it is sufficient to go with the simplest case (which is not too far from most empirical estimates) of unitary elasticity. That is, the model will be made Cobb-Douglas throughout.

In stating the model, it is also convenient to make some simplifying choices of units. Letting unskilled labor be the numeraire, I choose units so that in autarky the prices of both goods are one. I also measure skilled labor in units of half a worker-a trick normalization that implies an autarky relative wage that is also one. To be consistent with this normalization, the economy's endowment is assumed to consist of sixty units of unskilled and eighty revised units of skilled labor.

Given these choices of units, and the parameter values listed above, output and factor markets in the OECD can be represented by the following equations:

First, letting $w$ be the relative wage of skilled labor (one in autarky) gives expressions for average cost-which must equal prices if both goods are produced in the OECD.

$$
P_{1}=w^{2 / 3}, P_{2}=w^{1 / 3} .
$$

22. Lawrence and Slaughter (1993).

23. Sachs and Schatz (1994). 
Next, expressions for the unit input choices for both factors in both sectors may be written

$$
a_{S 1}=\frac{2}{3} w^{-1 / 3}, a_{U 1}=\frac{1}{3} w^{2 / 3}, a_{S 2}=\frac{1}{3} w^{-2 / 3}, a_{U 2}=\frac{2}{3} w^{1 / 3} .
$$

Given these input coefficients, output is determined by the requirement of full employment of both factors. These conditions may be written

$$
L_{S}=a_{S 1} Q_{1}+a_{S 2} Q_{2}, L_{U}=a_{U 1} Q_{1}+a_{U 2} Q_{2},
$$

which yield the output equations

$$
Q_{1}=D^{-1}\left[a_{U 2} L_{S}-a_{S 2} L_{U}\right], Q_{2}=D^{-1}\left[-a_{U 1} L_{S}+a_{S 1} L_{U}\right],
$$

where

$$
D=a_{S 1} a_{U 2}-a_{S 2} a_{U 1} .
$$

Given the output and prices of the two goods, it is straightforward to calculate the implied trade vector. In fact, the relevant number is the share of OECD-NIE trade in OECD output; this is simply the difference between the share of good 1 in output and in consumption:

$$
T=\frac{P_{1} Q_{1}}{P_{1} Q_{1}+P_{2} Q_{2}}-\frac{4}{7} .
$$

Equations 10-15, then, lead from an assumed relative wage to the implied relative prices and share of trade in output. It is also possible, therefore, to reverse the procedure, and ask how large a change in relative wages in the OECD might be associated with the emergence of NIE trade on the scale actually seen. And the answer is that trade on this scale should be associated with a fairly small wage change-and a very small change in relative prices.

Table 6 shows the implications of a 3 percent rise in the relative wage of skilled workers from its autarky level. It turns out that this is large enough to imply NIE trade of 2.2 percent of OECD gross product; which is more than the actual share of NIE manufactures in OECD spending. Yet this wage rise would be associated with a rise of only 1 percent in the relative price of skill-intensive goods. Admittedly, this exercise is carried out not only with a highly stylized model, but also on the assumption of unitary elasticities of substitution in production and consumption. If these elasticities were lower, the implied change in relative 
Table 6. Implications of a 3 Percent Rise in Relative Wages of Skilled Workers Percent

\begin{tabular}{lr}
\hline Share of NIE exports in OECD output & 2.2 \\
Change in relative price of good 1 & 1.0 \\
Change in output of good 1 & 2.8 \\
Change in output of good 2 & -6.9 \\
Change in real wages of unskilled workers & -1.7 \\
\hline
\end{tabular}

Source: Author's calculations based on model described in text.

wages would be larger. Nonetheless, the exercise helps to explain why studies that attempt to infer the effects of trade on income distribution by looking at prices have failed to find any clear-cut effects: for plausible parameter values, the change in relative prices associated with the growth of NIE trade should be well within measurement error.

\section{The Limits to Factor Price Equalization}

Some of those who worry about the effects of NIE exports on OECD labor markets might accept that these effects have been fairly small so far; but they would argue that these effects will become much larger, as industrialization spreads. It is possible to make a counterargument: As newly industrializing countries grow, their comparative advantage may shift away from products of very low skill intensity. Is it really likely that skilled labor will be a scarcer commodity in the world economy twenty years from now than it is today? But it is worth asking how large the potential effects of trade on OECD income inequality could be in a sort of worst case scenario.

An extreme view would be that growing international trade will lead to full factor price equalization: that wages for unskilled labor in OECD countries will be driven down toward their average levels in the world as a whole. Indeed, it might seem that this is precisely what conventional trade theory would predict: in the absence of any barriers to trade, isn't trade a substitute for factor mobility?

This extreme view, however, neglects an important limitation to the factor price equalization theorem: it only works as long as a country remains nonspecialized. If the change in relative prices is so large that the OECD no longer produces goods that compete with low-skill imports, any further reduction in the relative price of these goods will have no 
effect on income distribution. (This is why Wood's insistence that NIE exports are noncompeting is so puzzling: surely this is exactly the case in which the tendency toward factor price equalization breaks down? ${ }^{24}$ )

In the context of my miniature CGE model, it is straightforward to find the limits of factor price equalization. At a relative wage of skilled labor 50 percent above its autarky level, and a corresponding relative price of the skill-intensive good 14.5 percent above its original level, the OECD economy becomes completely specialized in the skill-intensive good. Any further change in the relative price has no effect on relative wages.

Even this case, however, seems unlikely to occur because it implies unreasonably large trade volumes. At the point of OECD specialization, manufactured imports from the NIEs would reach 28.6 percent of OECD gross product! In the context of this model, this is possible. If the model were modified to make a reasonable percentage (at least 60 percent) of OECD expenditure fall on nontraded goods and services, the point of complete specialization in traded goods would be reached after a substantially smaller change in income distribution. ${ }^{25}$

The flexible-wage version of the model, then, suggests that NIE trade can explain only a fraction of the huge increase in income inequality that has occurred in the United States since the 1970 s. ${ }^{26}$ And while it shows that larger effects from such trade could occur in the future, it also points

24. See Wood (1994).

25. For example, adding a nontraded sector that receives 60 percent of expenditures, and assuming that this sector initially uses skilled and unskilled labor in the same proportions as the OECD endowment, the model says that NIE trade can raise the relative wage of skilled labor by at most 17 percent.

26. The comparison between the European and the American cases may seem to suggest that a little bit of wage flexibility goes a long way, and to make one wonder whether even Eurosclerotic economies are really unable to adjust relative wages by a few percent. It is important to be careful about making too much of this. First, the estimated impact of NIE trade in the European case amounts to roughly 20 percent of the rise in European unemployment since the early 1970s, while the impact in the American case amounts to roughly 10 percent of the rise in U.S. wage inequality over the same period; given the number of ad hoc assumptions involved, this is not a major difference. Second, one should not fall into the fallacy of imagining that since any adverse shock can be decomposed into many smaller components, adjustment is always easy! (Achilles can, in fact, outrun the tortoise.) Rising European unemployment is presumably the result of a number of factors. Any one of these factors could have been offset by a small change in relative wages; but to offset them all would presumably have required something comparable to the massive growth in inequality that has occurred in the United States. 
out that there are limits to the change in relative wages that trade flows can produce.

\section{Conclusions}

The expansion of world trade is a topic that inspires hyperbole. Seemingly sober commentators are easily caught up in a rhetoric that portrays the growing integration of markets in recent years as an unprecedented event that changes all the rules for economic analysis and policy. And many observers, contemplating the rapid growth of manufactured exports from low-wage countries, have sounded ominous warnings about the effect of trade on advanced-country labor markets.

The truth is considerably more prosaic. International trade has risen substantially since World War II. Much of that growth, however, simply reflects a recovery to levels achieved before World War I. While world trade is a larger share of world production than ever before, the United States is still considerably less dependent on trade than most other advanced countries were a century ago.

It is true that there are new aspects to international trade. Of these, the most conspicuous and also most controversial is the growth of lowwage manufactured exports. This growth almost certainly has had some role in the growth both of unemployment in Europe and of wage inequality in the United States. A sober assessment does not, however, support the view that NIE trade is the principal cause of these labor market problems; nor does it support apocalyptic predictions about the future effects of that trade.

Perhaps the most important thing to say involves methodology-how to think about the global economy. One of the disturbing aspects about much of the popular and even the professional discussion of world trade has been its casualness. Commentators talk loosely of countries competing like big corporations, or of unskilled workers competing with their counterparts in the third world; they rarely ask whether their stories are logically consistent, let alone whether sweeping assertions about the implications of world trade can be reconciled with the relatively modest magnitudes of actual trade flows and price changes.

There is a way to think systematically about the effects of growing world trade: it is called general-equilibrium trade theory. Indeed, the hot 
current topic of NIE trade in manufactures is almost tailormade for analysis using the techniques developed decades ago by Jagdish Bhagwati, T. N. Srinivasan, Ron Jones, and their students. These are textbook models whose time has come. 


\section{Comments and Discussion}

Richard N. Cooper: This is a splendid paper. It is simple, elegant, easy to read once you get into the framework of the trade theory that Krugman uses. It makes a silk purse out of a sow's ear in the sense of turning a highly simplified and abstract teaching model into a tool to provide quantitative - not just qualitative-insight about the real world. I will offer two comments on the paper, one relatively brief and one longer. Both are empirical in nature.

The first point concerns Krugman's view that world trade in the last half century, at least until the early 1980 s, basically represents a return to 1913. I believe he understates the extent to which barriers to trade have declined during the whole period. I refer, especially, to technological improvements in transportation.

It is true that the steel hull and the screw propeller were known by 1870 , and that they were really important innovations in ocean transport. But the average merchant ship in 1950 was between 5,000 and 10,000 tons, compared with modern ships of 150,000 tons and over, such as supertankers, bulk carriers, container ships, and roll-on-roll-off ships. These large ships have greatly reduced the cost of ocean transport, particularly for low-value items, such that even iron ore and steam coal can be shipped economically for long distances. Europe can import coal from South Africa, Japan from Australia, the United States can import iron ore from Liberia, and so forth. This kind of trade was not generally economical in 1913. It is true that coal was shipped long distances, but that was mainly to coaling stations as fuel for ships, and not for use on land.

Much more significant than those developments, in my view, has 
been the evolution of air freight with the emergence of the long-distance jet airliner in 1958 and, especially, of the wide body jet in 1967.

It may come as a surprise, but 29 percent of U.S. exports by value and 21 percent of U.S. imports traveled by air in 1993. (These figures, of course, include trade in aircraft.) These shares have been growing steadily. If we exclude trade with Canada and Mexico, much of which is overland, then over 40 percent of U.S. overseas exports go by air, and nearly 30 percent of imports.

This represents a staggering change in the modes of international trade from twenty or thirty years ago. Cut flowers, formerly a local item, are now tradable over great distances. Israel is a big exporter of cut flowers to the United States. Air freight also permits the international organization of production slicing, which Krugman addresses, and combines it with just-in-time. Goods can leave Singapore today and arrive anywhere in the United States tomorrow.

Also noteworthy, as Krugman acknowledges, is a marked decline in the legal barriers to trade since the 1930s. Much of this represents a return to 1913; but we have gone way beyond 1913. Tariff levels on industrial products imported into the industrialized nations are now less than 10 percent of those in 1947 , before the first of the eight GATT rounds of multilateral trade negotiations took place. Trade among industrial countries, meaning Europe and Japan, was ridden with quantitative restrictions at that time. Those are virtually gone now.

Those of us who till the fields of trade policy wring our hands over the multifiber agreement, antidumping duties, and current quantitative restrictions on agriculture and so-called voluntary export restraints. But these are small barriers compared to what existed in Europe and Japan in the 1950s and even the early 1960s, and in developing countries, as Krugman points out, as late as the 1980s. The large import liberalizations of the last decade have not just completed the reductions agreed on at the Tokyo Round in 1979. Many developing countries have made unilateral liberalizations beyond these international agreements.

Let me turn to the second part of the paper. Although it is quantitative, it has the great merit of being free of facts. It is thus not possible to quarrel over the quality of Krugman's data, or the statistical significance of his econometric equations, which is the normal practice at Brookings Panel meetings.

This analysis is quite explicitly an illustrative exercise. With Krug- 
man's choice of parameters, which he draws from a combination of the professional literature, judgment, and the requirement for internal consistency, and under what he calls the European model, which assumes fixed real wages, all existing North-South trade in manufactured goods would reduce employment by 1.4 percent in the North.

The level of trade that we actually observe would alter the skilledunskilled wage differential by 3 percent under flexible wages and actually reduce real wages of unskilled workers by 1.7 percent, compared with a situation involving no trade.

Those are Krugman's quantitative findings. How do these figures compare with the growing number of empirical estimates that have been developed over recent years, some of them in Brookings Papers on Economic Activity? I report five for comparison.

George Borjas, Richard Freeman, and Lawrence Katz impute a maximum of 15 percent of the growth in the college-noncollege wage differential over the 1980 s to imports. ${ }^{1}$

Lawrence and Slaughter, coming at this with the perspective of trade rather than labor economists, find that trade cannot explain any of the growth in wage differentials. In fact, based on their assessment of the way commodity prices moved and the way factor prices must move, they conclude that, if anything, trade "nudged relative wages toward greater equality." 2

Sachs and Shatz, also in a Brookings Panel paper, attribute 6.2 percent of the decline in unskilled employment in manufacturing over the 1980 s to imports, on the very strong assumption that trade shares are frozen at their 1978 levels. ${ }^{3}$ They criticize Lawrence and Slaughter for not observing trends, yet they fall into the same error themselves by making this key assumption. If they permitted a continuation of previous trends in import ratios, they would find that imports had a smaller effect.

Wood, who has written an entire book on North-South trade and its impact on labor markets in the North, attributes 5 percent of the decline in employment in manufacturing in the OECD area to imports from developing countries. He then arbitrarily multiplies that number by four

1. Borjas, Freeman, and Katz (1992).

2. Lawrence and Slaughter (1993).

3. Sachs and Shatz (1994). 
to allow for services, which he does analyze explicitly, and for what he considers to be important trade-induced innovation, which on his argument will be biased against unskilled labor. ${ }^{4}$ (In that, I believe he is quite wrong.)

I have joined the growing crowd in this cottage industry with a partialequilibrium analysis. ${ }^{5} \mathrm{I}$ am troubled by the common practice of treating production workers as unskilled and nonproduction workers as skilled. That seems much too coarse an assumption. I focus instead on the least skilled members of the labor force, measured by the wage profile. This criterion directs attention to the textile, apparel, and leather (TAL) industries. I conclude that 10 percent of the relative decline in the wages of unskilled production workers can be attributed to imports into the United States of unskilled-labor-intensive goods, that is, TAL goods.

I apply the same model to the six largest European countries, of which the Netherlands is the smallest. Surprisingly, I find that relative wage movements, although less dramatic than in the United States, generally have been sufficient to absorb the unskilled labor released by the TAL industries. The significant exception is France, where the wage structure was exceptionally rigid over the 1980s. That has to do, inter alia, with the fact that France has the world's highest minimum wage.

How do I justify a partial-equilibrium analysis and a focus on the textile, apparel, and leather industries? Here, let me introduce some relevant facts about the United States (similar facts hold for the European countries), which Krugman's model ignores.

There were thirteen million production workers in U.S. manufacturing in 1990. In the three industries that I focus on, there were 1.9 million. The decline in the number of production workers in manufacturing over the 1980 s amounted to about one million, of which 40 percent were in the TAL industries. Thus the bulk of the decline in employment of unskilled workers, measured by the wage profile, was in these three industries.

Those figures have to be contrasted with the twenty-seven million production workers in U.S. retail trade, restaurants, and hotels in 1990 , whose number grew by six million over the decade. These include the McDonald's hamburger flippers that we keep hearing about. Again, by the wage profile these are the least skilled members of the American labor force.

4. Wood (1994).

5. Cooper (1994). 
The key point is that the employment changes in the tradable manufacturing sector were relatively small against the large scale and the large increase of employment in the nontradable sectors. I calculate the import-induced reduction in employment in the TAL industries, and in the in relative wage movements needed to absorb those released workers into the huge nontradable sector, which has a big demand for unskilled workers. The result is the 10 percent mentioned earlier. Like Krugman, I expected to find some unemployment effects in Europe due to wage rigidities, but I discovered that wage flexibility was sufficient, except in France, to absorb workers released from the TAL industries into the retail sector.

Let me close with some remarks on the intellectual framework behind my analysis because it is rather different from Krugman's. The big differences are that he discounts the large nontradable sector, and also relies, in a decisive way, on complete homogeneity of the traded goods.

While imported manufactured goods may be good substitutes for domestic products, they are not completely homogenous, and this is an important difference. I find, as Lawrence and Slaughter do, that the relative (value added) prices of textiles, apparel, and leather goods to all manufactured goods rose over the decade of the 1980s.

How can that happen in the face of stiff import competition? Import competition from developing countries puts indigenous industries under competitive pressure, and they respond in two ways. The first is by consolidating, shedding labor, and perhaps going out of business. The other is by upgrading their product. Firms try to differentiate their products. Under these conditions, it is possible for the price of import goods to fall even while the price of competing domestic goods rises, because they are for slightly different products that serve the same function: men's shirts, for example. On this view, labor is shed from the tradable sector even with flexible wages. The question then becomes: How good is the economic system at absorbing the released labor with little decline in wages? That is where a large nontradable sector plays a critical role.

In summary, Krugman's results do a nice job of bounding the impact of import competition in the context of classical trade theory and identifying why the plausible effects are small. But two elements of realism would modify his model. First, because goods are nonhomogenous, complete specialization in similar but differentiated goods may occur earlier than Krugman allows. Second, the existence of a large nontrada- 
ble sector limits the impact of competition from imports on domestic wages.

T. N. Srinivasan: I enjoyed reading Krugman's paper and, as always, was rewarded with penetrating insights and left with envy at his elegant and parsimonious modeling. His earlier inveighing against vacuous notions of competitiveness and dangerous practices of managed trade, through its cogent reasoning, put all rational individuals in his debt. He has now done a great service by analyzing an issue in which emotions, rather than reasoning, have played a major role.

Richard Cooper, in his masterly way, has surveyed the scene and has preempted several of my points. I will just add one or two with respect to the facts relating to trends in international trade. Krugman quotes the proportion of trade to GDP, going all the way back to 1850 . Anyone who has looked at how trade and GDP data are put together would caution against placing too much reliance on these numbers. ${ }^{1}$ Even if they were reliable, it would be hard to interpret them. After all, theory does not indicate a monotone relation between GDP growth and the trade-toGDP ratio. For example, take the standard Cass-Koopmans model of optimal growth in an economy that is specialized in producing consumer goods and imports investment goods. Suppose there is no population growth, capital lasts forever, and there are no intercountry capital movements. Given a positive discount rate, there exists a unique steady state in which the investment rate is zero. As such, imports would also be zero. During the transition to the steady state from an initial capital stock that is below its steady state value, there would be investment and hence, imports and a positive trade-to-GDP ratio that converges to zero in steady state along an optimal growth path. Thus in theory it is possible for the trade-to-GDP ratio to decline rather than increase as GDP grows.

As Krugman points out, geographical aggregation matters. Think of a two-country trading world, with each country specialized in its own export good, and importing what it consumes entirely from the other country. The trade-to-GDP ratio would be 200 percent for each country, by definition, because exports and imports both equal the value of GDP.

1. See, for example, Rozanski and Yates (1994) and Srinivasan (1994). 
Now if the two countries combine and form a one-country world, then all international trade disappears and the ratio falls from 200 percent to 0 percent! Krugman also mentions the changing characteristics of international trade and draws attention to the increasing importance of intraindustry trade. Depending upon geographical and temporal aggregation, as well as aggregation over states of nature, published data could magnify the extent of intra-industry trade.

I agree with Cooper that it is an exaggeration to suggest, as Krugman does, that all the major technological innovations influencing trade are those relating to transport and communications, and that these (namely the railroad, the steamship, and the telegraph) had already taken place on the eve of World War I. Let me give an example of how a process innovation could also enable the slicing up of the value added to which Krugman draws attention. This relates to the steel industry, which figures in the beautiful mural by Diego Rivera in Detroit mentioned by Krugman. In this mural, apparently, at one end there are blast furnaces and at the other end automobiles come out. Now there is a process for producing steel using natural gas as a reducing agent instead of coke. This process produces sponge iron which, in turn, is used along with steel scrap in electric arc furnaces.

With this process there is no need to have a steel plant next to a coal mine or an iron ore mine, and there are no significant scale economies. The steel industry became "footloose"-and many "mini" steel plants of this nature have come up all over the world. Krugman understates the importance of such process innovations, as well as recent technological changes such as jumbo jets for passenger and cargo transport, containerization, computer and communication technology, in the slicing-up of value added.

Krugman is right in emphasizing that massive reductions in trade barriers since 1913 have contributed to the growth in world trade. However, the trend toward increasing barriers in the post-World War II era is more important than Cooper allows. He suggests that the textiles, apparel, and leather industries are more relevant than high technology industries for the debate on wage trends in the United States and Europe. But these are the very industries in which the barriers grew after the Second World War. The notorious multifibre arrangement (MFA) did not exist prior to 1960 . Initially it was a short-term agreement in cotton textiles, aimed mainly at exports from Japan; and it was soon extended to 
all fibers known to man and god. Besides, anytime a country that was not under the MFA began exporting a noticeable amount, the industrialized countries slapped a quota on it and brought it into the MFA! One should not, therefore, understate this tendency for increasing barriers to trade when it comes to exports from developing countries.

The Uruguay Round agreement will phase out MFA in ten years. The agreement also rules out the use of "gray area" measures such as voluntary export restraints, and brings greater transparency and discipline on the antidumping and countervailing duty actions. One hopes that the agreement will be implemented, and not violated or evaded. Unfortunately the United States has set a bad example with its recent unilateral decision to double tariffs on selected Japanese automobiles from levels that had earlier been bound under GATT, and by doing so without waiting for the dispute settlement mechanism of the World Trade Organization to decide on its complaint against Japan.

Before I turn to Krugman's stylized model of global trade, let me say that I agree with Leamer's withering criticism that many of the empirical studies, particularly those by labor economists, do not apply the standard theorems of international trade correctly. ${ }^{2}$ They do not recognize that trade is quintessentially an endogenous phenomenon. Besides, analyzing trade requires general-equilibrium thinking-partial-equilibrium models of labor economies are inappropriate. ${ }^{3}$

My skepticism of the empirical literature arises from the fact that observed changes in employment and wages over time are, in principle, influenced by changes in demand and supply in the relevant product and factor markets. A well-specified structural model that distinguishes exogenous forcing variables (possibly taste, technology, and policy shocks) from endogenous responses, and takes into account the relevant leads, lags, and expectations, has to be estimated with some plausible identifying restrictions. As Leamer rightly argues, we are most likely to make progress if the empirical model is linked clearly with some understandable theory. The empirical literature unfortunately fails, by this test, to be convincing.

Krugman's stylized model certainly provides an understandable theory. Whether it is more than a way of organizing our thinking for doing

2. Leamer (1994).

3. The essays in Bhagwati and Kosters (1994) provide a cogent critique of the literature. 
Figure D1. Adjustment under the "European" Model

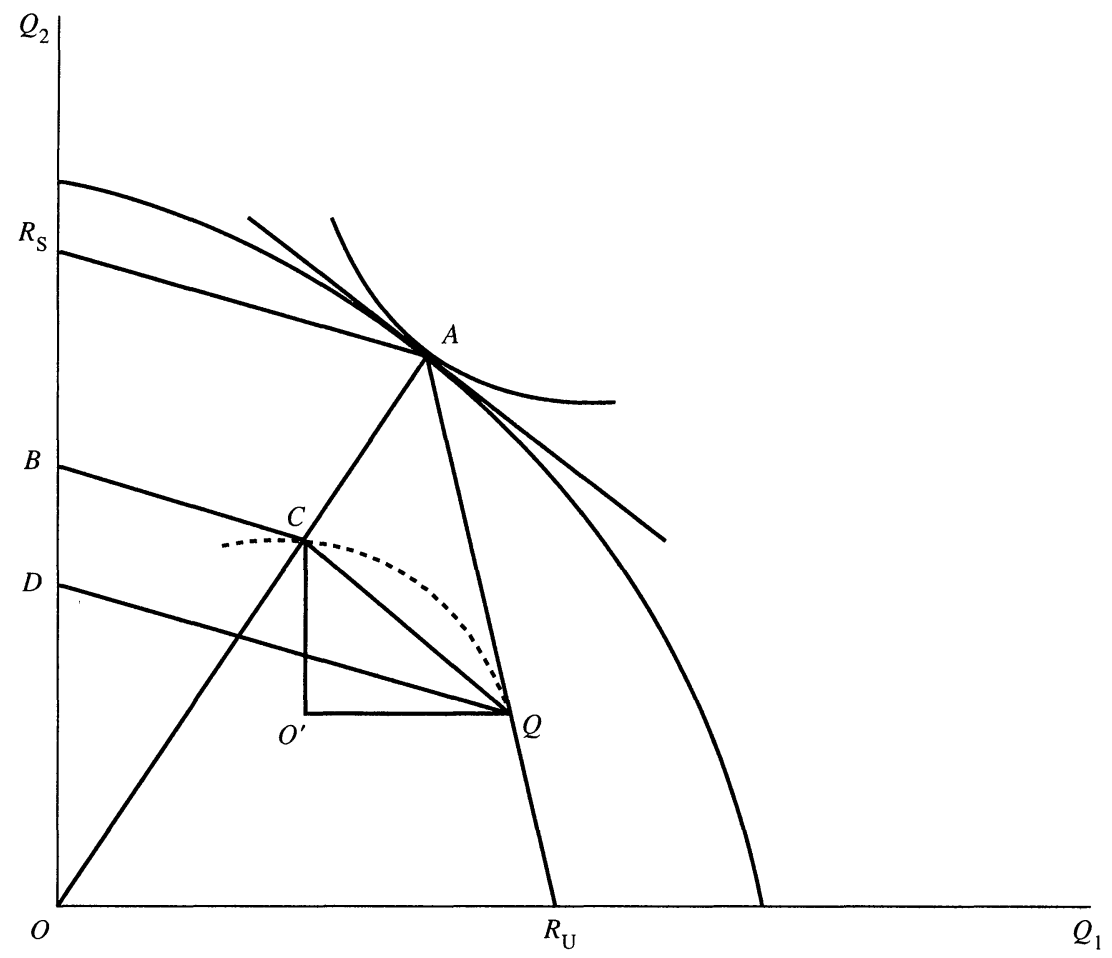

more serious empirical work is arguable. His figures 3, 4, and 5 have been collapsed into my figure D1. Start from autarky production and consumption point $A$. With relative wages and commodity prices (that is, the slope of the common tangent of the production possibility and Samuelson social indifference curves at $A$ ) fixed, the input coefficients in production remain unchanged. At $A$ there is full employment of both factors, unskilled and skilled labor, at the initial endowment levels. Now keeping the endowment of skilled labor fully employed, if we reduce the employment of unskilled labor, the production point (at fixed input coefficients) moves down the so-called Rybczynski line $A R_{U}$. Analogously, if we keep the endowment of unskilled labor fully employed but reduce the employment of skilled labor, the production point moves up the Rybczynski line $A R_{S}$. 
Now with the relative commodity price fixed, the only way to adjust to trade when it is opened is by adjusting in output and employment. Thus to generate the export of skilled-labor-intensive good 1 in exchange for imports of unskilled-labor-intensive good 2 supplied by the trading partners at the fixed commodity price, production has to move to $Q$ along the Rybczynski line $A R_{U}$, and consumption (given homothetic preferences) to $C$ along the ray $O A$. $C Q$ has the same slope as the fixed commodity price ratio. With $Q$ as the origin, the foreign offer curve of Krugman's figure 3 will pass through $C$, so that $C O^{\prime}$ units of good 2 are imported in exchange for $O^{\prime} Q$ units of good 1.

The unemployment of unskilled labor resulting from the shift in production from $A$ to $Q$ can be read by drawing a line parallel to the Rybczynski line $A R_{S}$ to meet the vertical axis at $D$. Clearly, by assumption, along $A R_{S}$ unskilled labor is fully employed, so that by choice of units of measurement we can make $O R_{S}$ represent the full employment of unskilled labor. By the same token, with input coefficients remaining the same, the employment of unskilled labor at $Q$ is the same as at $D$, and it can equal $O D$ by our choice of units. Thus unemployment is $D R_{S}$. By drawing a line parallel to $A R_{S}$ through $C$ to meet the vertical axis at $B$, it is seen the unskilled labor employment content of consumption is $O B$. Thus the unemployment due to the movement of consumption from $A$ to $C$ is $B R_{S}$. The unemployment arising from trade is $D B$, which is less than the total unemployment, $D R_{S}$, and $D R_{S} / D B$ is Krugman's multiplier effect. This indeed is the message of "European" adjustment, through output and employment changes but with no price or wage changes, to the opening up of trade.

I depict the "American" adjustment, which allows price and wage changes as well, in figure D2, where $O C$ is the foreign offer curve. Under free trade and full employment of both factors the American, or home, offer curve is $O F$, the slope of which at the origin is the autarky price, $O A$. Thus with price adjustment, equilibrium trade is at $T^{\prime}$, instead of at $T$ as in the "European" case with no adjustment. With the shapes of the offer curves as drawn, both the relative price of the unskilled-labor-intensive good and the volume of trade are obviously lower, at $T^{\prime}$. Thus allowing prices to adjust reduces the volume of trade to which consumption and production would have to adjust. Of course, as we saw earlier, the fall in relative price will lower the relative wage of unskilled labor enough to keep both factors fully employed.

Turning from the stylized model to the numerical simulations based 
Figure D2. Adjustment under the "American" Model

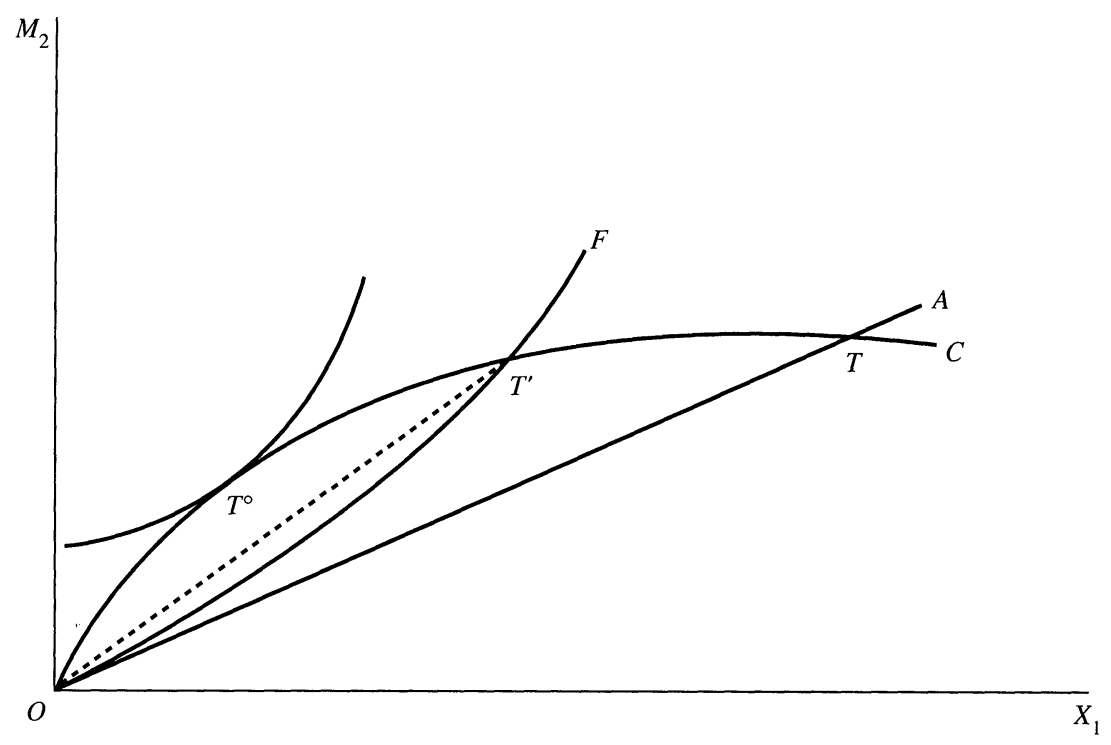

on it, I must admit to some skepticism as to their significance. The numerical calibrations that Krugman uses for his trade model might indeed capture the initial equilibrium configuration. However, in order to move from one equilibrium to another one has to make functional form assumptions as well. Krugman is candid in recognizing this when he says, "the model will be made Cobb-Douglas throughout." I am not as confident as he that the unitary elasticities of substitution are not "too far from most empirical estimates." Perhaps for the purposes he has in mind, namely, to demonstrate nonzero but modest effects of adjusting to trade à la Europe or à la America, the simulations are adequate. In any case, compared to most of the empirical estimates in the literature, which are not adequately grounded in some well-specified economic theory, Krugman's simulation at least has the virtue of coherence!

\section{General Discussion}

A number of panelists questioned the adequacy of Krugman's basic model for explaining unemployment. Maurice Obstfeld suggested that perfect labor mobility assumed in Krugman's “European" model leads 
it to understate the effect on unemployment. In Krugman's model the decline in the low-skill-intensive domestic industry only affects the unemployment of low-skilled workers; high-skilled workers displaced from this industry are readily absorbed in the expanded skill-intensive industry. This expansion employs some fraction of the unskilled as well. Under the extreme assumption that labor is completely immobile and assuming Krugman's factor intensities, a decline in the low-skill-intensive industry would give rise to 50 percent greater unemployment than in Krugman's calculations. Krugman discussed whether the nontradable sector itself is low-skill-intensive. Against Cooper's example of retail trade, Krugman offered school teachers, doctors, and chiropractors as types of skill-intensive jobs in the nontradable sector. He cited empirical research by Borjas, Freeman, and Katz which indicates that traded goods are slightly less skill-intensive than nontraded goods.

William Nordhaus suggested several feature of unemployment and the job market that were not captured by Krugman's simple model. Unemployment in Europe does not appear to be concentrated in one age or skill group, and net job losses in import-competing industries conceal significant job creation. Between 1973 and 1988 the apparel industry in the United States experienced job destruction of 14.4 percent and job creation of 10.8 percent, according to John Haltiwanger. These facts demonstrate that trade is only one of several influences on the labor market and imply that disentangling trade from factors such as technology will not be easy.

Nordhaus provided evidence that the ratio of shipments to value added for U.S. manufacturing establishments is actually smaller today than in 1930. Unless it turns out that particular tradable industries have evolved differently than these overall data indicate, this evidence calls into question Krugman's suggestion that "slicing up the value chain" is an important factor in explaining the increase in trade. While agreeing that trade liberalization in developing countries has played a key role in the dramatic acceleration in the world trade-to-GDP ratio since 1985, Maurice Obstfeld felt that Krugman gave too little attention to other factors. Trade in services has expanded as a proportion of overall trade, reducing the significance of transport costs. And treaties, the development of commercial law, greater familiarity with foreign business practices, and developments in capital markets which reduce the cost of trade credits have all facilitated trade expansion. 
There was some discussion of the difficulty in establishing a baseline for the growth of trade so as to be able to assess the importance of trade liberalization and other political changes. Krugman suggested that it is not obvious that the trade share should rise with income. One trend working in the opposite direction is that the share of nontradables in spending tends to rise as GDP rises. He reported research by Vern Henderson showing that single-industry towns in the United States may have over 50 percent of their employment outside of their main industry, but in Brazil the proportion is 30 to 40 percent. This suggests that economic growth may actually increase the demand for locally produced goods and services. In the same vein, world growth may spread the distribution of capital and technology.

The discussion turned to the importance of immigration to wage inequality. Benjamin Friedman observed that certain low-skill jobs in the nontradable sector seem to be performed disproportionately by immigrants for example, janitors, hotel staff, and barbers. In the presence of a shrinking demand for low-skill labor in the tradable sector, this would imply that immigration policy is important for the trend in wage inequality. He suggested that a policy favoring high-skill immigrants might make sense, especially since other policies to deal with inequality appear to be extremely expensive. For example, citing an estimate by James Heckman, he noted that a program seeking to amend the falling fortunes of the lowest income quintile via human capital investments would have a bill approaching two trillion dollars.

William Brainard suggested that even if economists do not consider immigration policy, politicians will. Throughout U.S. history, immigration policy has tended to change with the employment situation. Today it is certainly an important issue in California. Krugman noted that the movement of southern European guest workers between jobs in northern Europe has diminished, with a negative net migration from southern to northern Europe since 1973. However, Richard Cooper thought this can be explained by the fact that southern Europe has been booming, and is not necessarily due to policy changes in the north. 


\section{References}

Balassa, Bela. 1966. "Tariff Reductions and Trade in Manufactures among the Industrial Countries." American Economic Review 56(3):466-73. 1979. "The Changing International Division of Labor in Manufactured Goods." Banca Nazionale del Lavoro Quarterly Review, 130(Sept.):243-85.

Barraclough, Geoffrey, editor. 1978. The Times Atlas of World History. London: Times Books.

Bhagwati, Jagdish, and Marvin H. Kosters, editors. 1994. Trade and Wages: Leveling Wages Down? Washington: AEI Press.

Borjas, George J., Richard B. Freeman, and Lawrence F. Katz. 1992. "On the Labor Market Effects of Immigration and Trade." In Immigration and the Workforce: Economic Consequences for the United States and Source Areas, edited by George J. Borjas and Richard B. Freeman. Chicago: University of Chicago Press.

Brecher, Richard A. 1974. "Optimal Commercial Policy for a Minimum-Wage Economy.” Journal of International Economics 4(2):139-49.

Commission of the European Communities. 1993. Growth, Competitiveness, Employment: The Challenges and Ways Forward into the 21st CenturyWhite Paper. Luxembourg: Office for Official Publications of the European Communities.

Cooper, Richard N. 1994. "Foreign Trade, Wages, and Unemployment." Discussion Paper 1701. Cambridge, Mass.: Harvard Institute of Economic Research (November).

Frankel, Jeffrey A., Shang-Jin Wei, and Ernesto Stein. 1994. "APEC and Regional Trading Arrangements in the Pacific." Working Paper 94-1. Washington: Institute for International Economics (January).

Fuchs, Victor R. 1968. The Service Economy. New York: National Bureau of Economic Research.

Great Britain, Central Statistical Office. 1994. Annual Abstract of Statistics.

$\rightarrow$ Grubel, Herbert. 1967. "Intra-Industry Specialization and the Pattern of Trade." Canadian Journal of Economics 33:374-88.

Helpman, Elhanan, and Paul Krugman. 1985. Market Structure and Foreign Trade: Increasing Returns, Imperfect Competition, and the International Economy. Cambridge, Mass.: MIT Press.

Katz, Lawrence F. 1992-93. "Understanding Recent Changes in the Wage Structure." NBER Reporter (Winter): 10-15.

Lawrence, Robert Z., and Matthew J. Slaughter. 1993. "International Trade and American Wages in the 1980s: Giant Sucking Sound or Small Hiccup?" BPEA, Microeconomics, 2:1993, 161-210.

Leamer, Edward E. 1993. "Wage Effects of a U.S.-Mexican Free Trade Agreement." In The Mexico-U.S. Free Trade Agreement, edited by Peter M. Garber. Cambridge, Mass.: MIT Press. 
1994. "Trade, Wages and Revolving Door Ideas." Working Paper 4716. Cambridge, Mass.: National Bureau of Economic Research (April).

Liesner, Thelma. 1989. One Hundred Years of Economic Statistics. London: Economist Publications.

McCallum, John. 1995. "National Borders Matter: Canada-U.S. Regional Trade Patterns." American Economic Review 85(3): 615-23.

Mitchell, B. R. 1988. British Historical Statistics. Cambridge: Cambridge University Press.

Organisation for Economic Co-operation and Development (OECD). 1992. Historical Statistics 1960-1990. Paris: OECD.

Rozanski, Jerzy, and Alexander Yeats. 1994. "On the (In)Accuracy of Economic Observations: An Assessment of Trends in the Reliability of International Trade Statistics." Journal of Development Economics 44(1):103-30.

Sachs, Jeffrey D., and Howard J. Shatz. 1994. "Trade and Jobs in U.S. Manufacturing." BPEA, 1:1994, 1-69.

Samuelson, Paul A. 1949. "International Factor-Price Equalisation Once Again." Economic Journal 59(234):181-97.

Srinivasan, T. N. 1994. "Data Base for Development Analysis: An Overview." Journal of Development Economics 44(1):3-27.

United Nations. 1993. Trends in International Distribution of Gross World Product. National Accounts Statistics Special Issue. New York: United Nations.

United Nations Conference on Trade and Development (UNCTAD). 1994. Handbook of International Trade and Development Statistics 1993. New York: United Nations.

Wood, Adrian. 1994. North-South Trade, Employment and Inequality: Changing Fortunes in a Skill-Driven World. New York: Clarendon Press.

World Bank. 1994. World Development Report 1994: Infrastructure for Development. New York: Oxford University Press.

. 1995. Global Economic Prospects and the Developing Economies. Washington: World Bank. 